\title{
Hepatocyte Growth Factor Acts as a Motogen and Guidance Signal for Gonadotropin Hormone-Releasing Hormone-1 Neuronal Migration
}

\author{
Paolo Giacobini, ${ }^{1}$ Andrea Messina, ${ }^{1}$ Susan Wray, ${ }^{2}$ Costanza Giampietro, ${ }^{3}$ Tiziana Crepaldi, ${ }^{4}$ Peter Carmeliet,${ }^{5}$ and \\ Aldo Fasolo ${ }^{1}$ \\ ${ }^{1}$ Department of Human and Animal Biology, University of Torino, 10123 Torino, Italy, ${ }^{2}$ Cellular and Developmental Neurobiology Section, National \\ Institute of Neurological Disorders and Stroke, National Institutes of Health, Bethesda, Maryland 20892, ${ }^{3}$ Italian Foundation for Cancer Research Institute \\ of Molecular Oncology, 20139 Milan, Italy, ${ }^{4}$ Department of Anatomy, Pharmacology, and Forensic Medicine, University of Torino, 10125 Torino, Italy, and \\ ${ }^{5}$ Center for Transgene Technology and Gene Therapy, Flanders Interuniversity Institute for Biotechnology, University of Leuven, 3000 Leuven, Belgium
}

Reproduction in mammals is under the control of the hypothalamic neuropeptide gonadotropin hormone-releasing hormone-1 (GnRH1). GnRH-1-secreting neurons originate during embryonic development in the nasal placode and migrate into the forebrain along olfactory nerves. Gradients of secreted molecules may play a role in this migratory process. In this context, hepatocyte growth factor (HGF) is a potential candidate, because it promotes cell motility in developing brain and has been shown previously to act as a motogen on immortalized GnRH-1 neurons (GN11). In this study, the role of HGF and its receptor Met during development of the GnRH-1 system was examined. GnRH-1 cells express Met during their migration and downregulate its expression once they complete this process. Tissue-type plasminogen activator (tPA), a known HGF activator, is also detected in migratory GnRH-1 neurons. Consistent with in vivo expression, HGF is present in nasal explants, and GnRH-1 neurons express Met. HGF-neutralizing antibody was applied to explants to examine the role of the endogenous growth factor. Migration of GnRH-1 cells and olfactory axon outgrowth were significantly reduced, in line with disruption of a guidance gradient. Exogenous application of HGF to explants increased the distance that GnRH-1 cells migrated, suggesting that HGF also acts as a motogen to GnRH-1 neurons. Functional experiments, performed on organotypic slice cultures, show that creation of an opposing HGF gradient inhibits GnRH-1 neuronal migration. Finally, $\mathrm{tPA}^{-1-}: \mathrm{uPA}^{-1-}$ (urokinase-type plasminogen activator $^{-I-}$ ) knock-out mice exhibit strong reduction of the GnRH-1 cell population. Together, these data indicate that HGF signaling via Met receptor influences the development of GnRH-1.

Key words: GnRH-1; LHRH; HGF; migration; olfactory system; development

\section{Introduction}

Gonadotropin hormone-releasing hormone-1 (GnRH-1) regulates anterior pituitary gonadotropes and, as such, is essential for reproduction. GnRH-1-secreting neurons originate from the nasal placode (Wray, 2002) during embryonic development and migrate to the hypothalamus apposed to olfactory-vomeronasal nerves (Schwanzel-Fukuda et al., 1989; Wray et al., 1989). In humans, several monogenic disorders leading to isolated hypogonadotropic hypogonadism ( $\mathrm{IHH}$ ) are caused by disruption of GnRH-1 neuronal ontogeny/migration (Gonzalez-Martinez et al., 2004). However, mutations in these genes do not account for many individuals exhibiting IHH. This suggests that the full rep-

Received Sept. 12, 2006; accepted Dec. 6, 2006.

This work was supported by Compagnia di San Paolo (Neurotransplant Project 2004.2019), Ricerca Scientifica Applicata Comitato Interministeriale Programmazione Economica A23 Regione Piemonte, and Fondo per gli Investimenti della Ricerca di Base Grant RBNE01WY7P (Italy). We thank Andree Reuss for her help in generating nasal explants.

Correspondence should be addressed to Dr. Paolo Giacobini, Department of Human and Animal Biology, Via Accademia Albertina 13, 10123 Torino, Italy. E-mail: paolo.giacobini@unito.it.

D01:10.1523/JNEUROSCI.4979-06.2007

Copyright $\odot 2007$ Society for Neuroscience $\quad$ 0270-6474/07/270431-15\$15.00/0 ertoire of molecular cues regulating the GnRH-1 migratory process has not yet been identified.

Factors already shown to influence GnRH-1 neuron migration, either directly or indirectly via extension of olfactory axons (Wray, 2002; Wierman et al., 2004; Tobet and Schwarting, 2006), include neurotransmitters/neuropeptides (Fueshko et al., 1998; Bless et al., 2000; Simonian and Herbison, 2001; Pronina et al., 2003; Giacobini et al., 2004), surface molecules (Yoshida et al., 1999; Gamble et al., 2005), and growth factors (Cronin et al., 2004; Gill et al., 2004; Gill and Tsai, 2006). Guidance of the axonal/migratory pathway is also an important prerequisite for establishment of the adult-like GnRH-1 cell distribution (Wray, 2002), and classical chemoattractants [(e.g., netrin-1 and stromal cell-derived factor-1 (SDF-1)] or chemorepellents (e.g., reelin) are distributed in gradients along the GnRH-1 migratory route and participate in directing appropriate migration (Schwarting et al., 2001, 2004, 2006; Cariboni et al., 2005).

Hepatocyte growth factor (HGF) is a cytokine that, via its receptor Met, exhibits mitogenic, motogenic, and chemoattractive activities in neuronal (Ebens et al., 1996; Maina et al., 1997; Streit and Stern, 1997; Yamamoto et al., 1997; Caton et al., 2000; 
Ieraci et al., 2002; Gutierrez et al., 2004) and non-neuronal cells (Stella and Comoglio, 1999; Urbanek et al., 2005; Son et al., 2006). HGF and Met are widely distributed in developing brain (Jung et al., 1994; Thewke and Seeds, 1996; Achim et al., 1997; Thewke and Seeds, 1999; Korhonen et al., 2000); however, few studies address the function(s) of Met signaling during brain development. To date, HGF has been shown to have motogenic effects on migrating cortical neurons (Powell et al., 2001, 2003; Segarra et al., 2005). HGF is expressed in nasal embryonic mesenchyme with an increasing gradient toward the border between the nose and telencephalon (Sonnenberg et al., 1993; Thewke and Seeds, 1996). This pattern suggests that HGF/Met signaling might impact developmental events in the GnRH-1/olfactory system. In support of this, HGF exerts motogenic and chemotactic effects on the GN11 immortalized GnRH-1 cell line (Giacobini et al., 2002).

To determine the role of HGF in the developing GnRH-1/ olfactory system, this study (1) characterized Met expression in nasal regions during the period of GnRH-1 neuronal migration, (2) perturbed HGF/Met signaling in two in vitro models (nasal explants and slice cultures) in which primary GnRH-1 neurons are maintained and cellular movement can be quantified, and (3) assessed the impact of the lack of HGF activators [plasminogen activators (PAs)] on the GnRH-1 neuronal population in PA knock-out $(\mathrm{KO})$ mice.

\section{Materials and Methods}

Animals

Experiments were conducted in accordance with current European Union and Italian law, under authorization of the Italian Ministry of Health, number 66/99-A.

CD-1 embryos (Charles River Laboratories, Milan, Italy) were harvested at embryonic day 11.5 (E11.5), E12.5, E14.5, and E17.5 (plug day, E0.5) and used for RNA isolation, immediately frozen and stored $\left(-80^{\circ} \mathrm{C}\right)$ until laser-capture microscopy, or postfixed [overnight; $4 \%$ paraformaldehyde (PFA) in $0.1 \mathrm{~m}$ phosphate buffer, $\mathrm{pH} 7.4$ ] and cryoprotected and then frozen and stored $\left(-80^{\circ} \mathrm{C}\right)$ until processing for immunocytochemistry. Tissue-type $\mathrm{PA}^{-l-}\left(\mathrm{tPA}^{-l-}\right)$ :urokinase-type $\mathrm{PA}^{-1-}\left(\mathrm{uPA}^{-1-}\right)$-deficient mice and wild-type (WT) background control mice (C57B16/129sv) were provided by Prof. P. Carmeliet [Center for Transgene Technology and Gene Therapy, Flanders Interuniversity Institute for Biotechnology, University of Leuven, Leuven, Belgium)]. CD-1 postnatal day 10 (PN10) mice and adult knock-out and WT animals were anesthetized with an intraperitoneal injection of ketamine $(200 \mathrm{mg} / \mathrm{kg})$ and perfused with $4 \%$ paraformaldehyde. The brains were dissected and postfixed in the same fixative overnight at $4^{\circ} \mathrm{C}$, cryoprotected in sucrose solutions, and then frozen and stored $\left(-80^{\circ} \mathrm{C}\right)$ until processing for immunohistochemistry.

\section{Nasal explants}

Nasal regions were cultured as described previously (Fueshko and Wray, 1994). Briefly, embryos were obtained from timed pregnant animals in accordance with National Institutes of Health (NIH)/National Institute of Neurological Disorders and Stroke guidelines and Animal Care and Use Committee approval and with current European Union and Italian law. Nasal pits of E11.5 staged NIH-Swiss embryos were isolated under aseptic conditions in Gey's balanced salt solution (Invitrogen Grand Island, NY) enriched with glucose (Sigma-Aldrich, St. Louis, MO). Nasal explants were adhered onto coverslips by a plasma (Cocalico Biologicals, Reamstown, PA)/thrombin (Sigma-Aldrich) clot. The explants were maintained in defined serum-free medium (SFM) (Fueshko and Wray, 1994 ) at $37^{\circ} \mathrm{C}$ with $5 \% \mathrm{CO}_{2}$. From culture day 3 to day 6 , fresh medium containing fluorodeoxyuridine $\left(8 \times 10^{-5} \mathrm{M}\right.$; Sigma-Aldrich $)$ was given to inhibit proliferation of dividing olfactory neurons and non-neuronal explant tissue. The medium was changed to fresh SFM twice a week.

\section{Transcript analyses}

All primers were designed from published GenBank sequences and screened using BLAST (basic local alignment search tool) to ensure spec- ificity of binding. Primers were pretested on brain cDNA and thereafter used throughout the described protocols at a concentration of $250 \mathrm{~nm}$. Amplified products were run on a 1.5\% agarose gel.

\section{Reverse transcription-PCR analysis}

Total RNA was isolated from noses and brains obtained from E11.5 mice using RNA STAT-60 (Tel-Test, Friendswood, TX) following the manufacturer's protocol. Briefly, the tissue was homogenized ( $1 \mathrm{ml}$ of RNA STAT-60 per $50-100 \mathrm{mg}$ of tissue), chloroform was added $(0.2 \mathrm{ml} / \mathrm{ml}$ homogenate), and the mixture was spun. To the aqueous layer, isopropanol was added $(0.5 \mathrm{ml})$ to precipitate RNA. RNA pellet was washed (75\% ethanol), air dried, and resuspended (DEPC-treated water). Total RNA from adult mouse brain served as positive control tissue. For the reverse transcription (RT)-PCR, $0.5 \mu \mathrm{g}$ of each sample was used. Firststrand cDNA was synthesized using the SuperScript III First-Strand Synthesis System for RT-PCR (Invitrogen) following the manufacturer's instructions. PCR was performed using $4 \mu \mathrm{l}$ of $\mathrm{cDNA}$ and the appropriate oligonucleotides in $30 \mu \mathrm{l}$ PCRs using standard reaction buffer [(in mM) 10 Tris- $\mathrm{HCl}, \mathrm{pH} 8.3,50 \mathrm{KCl}$, and $1.5 \mathrm{MgCl}_{2}$ ], $0.8 \mathrm{~mm}$ deoxynucleotide triphosphate (Invitrogen) and $0.025 \mathrm{U} / \mu \mathrm{l}$ REDTaq DNA polymerase (Sigma-Aldrich). The following primers were used: 5'-GGGACTGCAGCAGCAAAGC-3' and 5'-GTCTGAGCATCTAGAGTTTCC-3' for c-met amplification (Chan et al., 1988). For HGF, 5'GGGGAATGAGAAATGCAGTCAG-3' and 5' $^{\prime}$-CCTGTATCCATGGATGCTTC-3' were used (Tashiro et al., 1990). The number of cycles and the annealing temperature used for each primer pair were as follows: 25 cycles and $59^{\circ} \mathrm{C}$ for c-met; 30 cycles and $55^{\circ} \mathrm{C}$ for HGF. No products were amplified in water or brain RNA not reverse transcribed.

\section{Laser capture microdissection and RT-PCR on}

\section{tissue-specific regions}

Laser capture microdissection (LCM) permits cells to be isolated ("captured") from tissue sections for molecular analyses. In this study, olfactory epithelium (OE), vomeronasal organ (VNO) epithelium, and lower jaw were captured from E14.5 and E17.5 mouse frozen sections (see Fig. $1 C, D)$ using a PALM LCM system (Zeiss, Thornwood, NY). The lasermicrodissected tissues were popped into a sterile Microfuge cap containing $1 \mu \mathrm{l}$ of $0.1 \%$ Triton X-100 and subsequently centrifuged for $1 \mathrm{~min}$ at $7500 \times g$ (maximum) to relocate material to the bottom of a sterile tube. Prime RNase inhibitor ( $7 \mu$ l diluted 1:100 in DEPC-treated water; Eppendorf, Hamburg, Germany) was added. Captured tissue was used to synthesize first-strand cDNA using the SuperScript III First-Strand Synthesis System for RT-PCR (Invitrogen) following the manufacturer's instructions. Controls without reverse transcriptase were performed to demonstrate the absence of contaminating genomic DNA. Brain total RNA was also reverse transcribed and used as a positive control.

PCR was performed for $\beta$ III-tubulin (a general neuronal marker), early B-cell factor 2 (EBF-2) [an olfactory transcription factor and thus marker of olfactory/vomeronasal receptor neurons (Wang et al., 1997)], c-met, and HGF at 40 cycles on a thermocycler (30 s denaturation at $94^{\circ} \mathrm{C}, 30 \mathrm{~s}$ annealing at $55-65^{\circ} \mathrm{C}$, and 2 min elongation at $72^{\circ} \mathrm{C}$ ). PCR primer pairs were as follows: $\beta$ III-tubulin forward primer, $5^{\prime}$-GAGGACAGAGCCAAGTGGAC-3'; $\beta$ III-tubulin reverse primer, $5^{\prime}$-CAGGGCCAAGACAAGCAG-3'; EBF-2 forward primer, 5'-TGCAGTAGTTGCTAACAGTGG-3'; EBF-2 reverse primer, 5'-TTTCCAATGCTAGAAGCCTAAC-3'.

\section{Cell isolation and PCR analysis}

Nasal explants were washed twice with $1 \times \mathrm{PBS}$ (without $\mathrm{Mg}^{+}$or $\mathrm{Ca}^{2+}$ ) and placed in $2 \mathrm{ml}$ of the same solution. GnRH-1-like neurons were identified by their bipolar morphology, association with outgrowing axons, and location within the explant (see Fig. $4 B$ ). At two time points [4.5 and $28 \mathrm{~d}$ in vitro (div) ], single GnRH- 1 cells ( $n=5$ for each in vitro stage) were isolated from nasal explants using a micropipette (see Fig. 4A-C) controlled by a micromanipulator (Narishige, Tokyo, Japan) connected to an inverted microscope (IX51; Olympus Optical, New Hyde Park, $\mathrm{NY}$ ), cDNA was produced, and PCR amplification was performed as described previously (Kramer et al., 2000; Giacobini et al., 2004). Briefly, a single cell was lysed and reverse transcribed [AMV (avian myeloblastosis virus) and MMLV (Moloney murine leukemia virus)-reverse tran- 
scriptases; $37^{\circ} \mathrm{C}$ for $15 \mathrm{~min} ; 65^{\circ} \mathrm{C}$ for $10 \mathrm{~min}$ ] using an oligo-dT primer $\left(50 \mathrm{OD} / \mathrm{ml} ; \mathrm{pd}(\mathrm{T})_{19-24}\right)$. The cDNA was end labeled with terminal transferase $\left(37^{\circ} \mathrm{C}\right.$ for $15 \mathrm{~min} ; 65^{\circ} \mathrm{C}$ for $\left.10 \mathrm{~min}\right)$. Subsequent PCR amplification was performed using AL1 primers [ATT GGA TCC AGG CCG CTC TGG ACA AAA TAT GAA TTC $(T)_{24}$ ] (Dulac and Axel, 1995) for 25 cycles in a DNA Thermal Cycler $\left(94^{\circ} \mathrm{C}\right.$ for $1 \mathrm{~min}, 42^{\circ} \mathrm{C}$ for $2 \mathrm{~min}$, and $72^{\circ} \mathrm{C}$ for 6 min, with $10 \mathrm{~s}$ of extension time at each cycle; PerkinElmer, Wellesley, MA). After the first 25 cycles, fresh Taq was added, and 25 more cycles of PCR were performed minus the $10 \mathrm{~s}$ extensions. The resulting product was phenol-chloroform extracted and then ethanol precipitated, and an aliquot was run on a $1.5 \%$ agarose gel. Total brain RNA $(1 \mu \mathrm{g})$ served as a positive control. All cDNA pools were initially screened for GnRH-1 (correct cell phenotype), $\beta$-tubulin, and L19 (two housekeeping genes, microtubule and ribosomal) using PCR. All cells used in this study were positive for all three transcripts. Primers sequences used were as follows: GnRH-1, 5' -GCTAGGCAGACAGAAACTTGC-3' and 5'-GCATCTACATCTTCTTCTGCC-3'; $\beta$-tubulin, described above; and L19, $5^{\prime}$ CCTGAAGGTCAAAGGGAATGTGTTC- ${ }^{\prime}$ and $5^{\prime}$-GGACAGAGTCTTGATGATCTCCTCC- $3^{\prime}$. Each reaction mixture was generated as described above, and $2 \mu \mathrm{l}$ of each primer and $1 \mu \mathrm{l}$ of template cDNA were added. The PCR program was as follows: $10 \mathrm{~min}$ at $94^{\circ} \mathrm{C}$ prerun; $30 \mathrm{~s}$ at $94^{\circ} \mathrm{C}, 30$ s at $55^{\circ} \mathrm{C}$ or $65^{\circ} \mathrm{C}$ (depending on primers), and $2 \mathrm{~min}$ at $72^{\circ} \mathrm{C}$, for 35 cycles; and $10 \mathrm{~min}$ at $72^{\circ} \mathrm{C}$ postrun. The same PCR profile was used for subsequent screening with the following primers: tPA forward primer ( $5^{\prime}$-AAGTTTGCACTGGGGACAAG-3'), tPA reverse primer $\left(5^{\prime}\right.$ TCCCAAGAGTTGAGGAGTGTG-3'), uPA forward primer ( $5^{\prime}$-GTCTTCCATGTGATGCTCCA- $3^{\prime}$ ), and uPA reverse primers ( $5^{\prime}$-ACCCAGTGAGGATTGGATGA-3'). Specific bands were observed in total E17.5 brain lanes, whereas no bands were seen in water lanes.

\section{Immunocytochemistry}

Primary antisera used were against GnRH-1 [SW-1, rabbit (Rb) polyclonal (Wray et al., 1988), kindly provided by Dr. S. Wray; LR-5, Rb polyclonal, kindly provided by Dr. R. Benoit, Montreal General Hospital, Montreal, Quebec, Canada; SMI41, mouse monoclonal antibody (Sternberger Monoclonals, Baltimore, MD)], HGF (\#AF294-NA, goat polyclonal; R \& D Systems, Minneapolis, MN) Met (\#SP260 and \#H-190, rabbit polyclonal, and \#B-2, mouse monoclonal IgG; Santa Cruz Biotechnology, Santa Cruz, CA), peripherin (\#AB1530, rabbit polyclonal; Millipore, Billerica, MA), neural cell adhesion molecule (NCAM; \#C9672, mouse monoclonal IgG; Sigma-Aldrich), and tPA (\#ASMTPA, rabbit polyclonal; Molecular Innovations, Southfield, MI).

Mouse tissue sections or nasal explants were immunocytochemically stained as described previously (Fueshko and Wray, 1994; Wray et al., 1994). Mouse embryos and postnatal and adult brains were cryosectioned respectively at $16 \mu \mathrm{m}$ (embryos) and free-floating at $30 \mu \mathrm{m}$ (postnatal or adult brains). These sections and explants were fixed with $4 \%$ formaldehyde for $1 \mathrm{~h}$ before immunocytochemistry. Briefly, sections or nasal explants were washed in PBS, incubated in 10\% NGS/0.3\% Triton $\mathrm{X}-100$ (NGS/Tx-100; $1 \mathrm{~h}$ ), washed several times in PBS, and placed in primary antibody (overnight at $4^{\circ} \mathrm{C}$ ). The next day, tissues were washed in PBS, incubated in biotinylated secondary antibody [ $1 \mathrm{~h} ; 1: 500$ in PBS/ $0.3 \%$ Triton X-100; goat anti-rabbit biotinylated (GAR-Bt; Vector Laboratories, Burlingame, CA); goat anti-mouse biotinylated (GAM-Bt; Millipore)], and processed using a standard avidin-biotin-horseradish peroxidase /3', 3-diaminobenzidine (DAB) protocol. For double immunoperoxidase staining, the chromogen for the first antigen-antibody complex was DAB [brown precipitate (Kramer and Wray, 2000)], whereas the chromogen for the second antigen-antibody complex was SG substrate (blue precipitate; Vector Laboratories). Primary antisera dilutions were as follows: anti-GnRH-1 (SW-1; 1:3000), anti-peripherin (1:2000), anti-Met (\#SP260 and \# H-190; 1:200). For doubleimmunofluorescence experiments, primary antisera were diluted as follows: anti-GnRH-1 (SW-1, 1:1000; SMI41, 1:3000), anti-NCAM (1:60), anti-HGF (1:10), anti-Met (\#SP260 and \# H-190; 1:100), and anti-tPA (1:500). Sections or nasal explants were incubated overnight $\left(4^{\circ} \mathrm{C}\right)$ in a mixture of primary antibodies diluted in NGS/Tx-100 and visualized using Alexa Fluor 488 and Alexa Fluor 568 conjugated secondary anti- bodies (1:500; Invitrogen). Anti-Met and anti-HGF antisera were incubated for two nights at $4^{\circ} \mathrm{C}$.

When two polyclonal primary antibodies were used (anti-Met/SW-1 and anti-tPA/SW-1), staining of the first antigen-antibody complex was performed with goat anti-rabbit Alexa Fluor 488 (1:500; Invitrogen) secondary antibody. This step was followed by a blocking reaction with an anti-rabbit Fab fragment (Jackson ImmunoResearch Laboratories, West Grove, PA) (Giacobini et al., 2004) for $1 \mathrm{~h}$ (RT), followed by PBS washes, fixation ( $4 \%$ formalin for $30 \mathrm{~min}$ ), and more PBS washes before application of the second primary antibody, which was visualized with conjugated fluorescent goat anti-rabbit cyanine 3 (Cy3; 1:800; Jackson ImmunoResearch Laboratories).

E12.5 slice cultures were fixed with 4\% PFA for $1 \mathrm{~h}$ and processed for immunohistochemistry. To detect GnRH-1 immunoreactivity, slices were incubated at $4^{\circ} \mathrm{C}$ for five nights with LR-5 antibody diluted 1:4000 in PBS containing 10\% NGS and 1\% Tx-100. For secondary antibody processing, slices were washed several times with PBS for $1 \mathrm{~h}$ before incubation overnight at $4^{\circ} \mathrm{C}$ with goat anti-rabbit Cy3 (1:500; Jackson ImmunoResearch Laboratories).

Specimen were mounted in DABCO (1,4-diazabicyclo[2.2.2]octane; Sigma-Aldrich) and observed with a laser-scanning Olympus Fluoview confocal system (Olympus Optical).

\section{Functional assays}

Nasal explant. To determine the function of HGF in the developing olfactory/GnRH-1 systems, pharmacological perturbations were performed, and olfactory axon outgrowth and GnRH-1 cell migration were quantified. Explants in experimental groups were maintained in SFM containing either a blocking HGF antibody ( $5 \mu \mathrm{g} / \mathrm{ml}$; \#AF294-NA; R \& D Systems) or $25 \mathrm{ng} / \mathrm{ml}$ human recombinant HGF (Sigma-Aldrich). Drug concentrations were based on data from previous migrational studies (Powell et al., 2001; Giacobini et al., 2002). Nasal explants were treated at 3 div with pharmacological agents for $72 \mathrm{~h}$. Control explants were maintained in SFM that was changed, as in the treatment groups, at 3 and 6 div. At 7 div, explants were processed for double-label immunocytochemistry for GnRH-1/peripherin (see above), and then the GnRH-1 cell migration as well as the maximum olfactory axon outgrowth were quantified as described below. Treatments performed at $1 \mathrm{div}$ (for $72 \mathrm{~h}$ ) did not induce any significant change in the parameters examined compared with control cultures (data not shown).

Quantification of GnRH-1 cell number, migration, and olfactory fiber outgrowth. For each explant, the number of GnRH-1-immunopositive cells was counted on the main tissue mass, as well as in the periphery of the explant (Fueshko et al., 1998; Giacobini et al., 2004). The main tissue mass contained the nasal pit/olfactory epithelial region, surrounding mesenchyme, and nasal midline cartilage (see Fig. 3, schematic). The periphery refers to the area surrounding the main tissue mass into which cells had spread and/or migrated. Data are presented as mean \pm SEM. Quantification of GnRH-1 cell migration and olfactory axon outgrowth was performed digitizing the stained explant. Images were taken under an Olympus IX50 inverted microscope (Olympus Optical) equipped with a CCD camera CoolSNAP-Pro (Media Cybernetics, Silver Spring) and images edited with Image-Pro Plus software (Media Cybernetics). For cell migrational measurements, a caliber with a series of concentric arcs separated by a uniform distance $(200 \mu \mathrm{m})$ was overlaid on the digitized image. The total number of cells in each zone of the periphery of the explant was recorded via computer-assisted analysis (Image-Pro Plus software; Media Cybernetics) (see Fig. 6). In general, under all treatment conditions, the number of GnRH-1 cells decreases as a function of distance from the main tissue mass. GnRH-1 cell migration was calculated as the distance from the main tissue mass edge to the outer sector of the periphery.

For fiber outgrowth measurements, the distance from the border of the explant at which the majority of peripherin-positive fibers ended was recorded; this method was chosen because the complex nature of the fiber network prevented quantification of individual fiber lengths. A mean distance for fiber outgrowth was obtained for each treatment group, and values were reported as the mean \pm SEM. All experiments 
used explants generated by different individuals on multiple culture dates.

Statistical analysis of fiber outgrowth was performed with a one-way ANOVA followed by Fisher's least significant difference (LSD) post hoc analysis $(p<0.05)$ using the statistical software SPSS 12.0 (SPSS, Chicago, IL). A mean total GnRH-1 cell number (inside the explant and/or in the periphery) was obtained for each treatment group and analyzed using a one-way ANOVA. These values were taken as an indication of GnRH-1 cell survival. Data for cell movement were compared for SFM and experimental groups by constructing contingency tables and applying the $\chi^{2}$ test for independence. This nonparametric analysis was chosen because zonal distance (200 $\mu \mathrm{m}$ grouping) was used instead of continuous measurements, and the number of observations per treatment (culture number) was not identical. A stringent $p$ value of 0.001 was chosen for significance in these experiments.

\section{HGF-expressing cells}

To obtain HGF clones in which expression of murine HGF can be specifically induced by doxycycline (Dox), we adopted the tetracycline (Tet)-Off technology described by Gossen and Bujard (1992). The mouse HGF cDNA was inserted in the bidirectional pBI response plasmid containing enhanced green fluorescent protein (EGFP) as a reporter gene (Baron et al., 1995), which makes it possible to trace cells expressing the transgene by EGFP imaging. The plasmid was introduced into stable Madin-Darby canine kidney (MDCK) Tet-Off cells, and clones resistant to blasticidin were selected and expanded. The HGF cDNA construct was amplified from murine HGF plasmid (a kind gift from Dr. W. J. LaRochelle) using the Platinum Pfx polymerase (Invitrogen) and the following oligonucleotides (Sigma-Aldrich): 5' -TTGCACGCGTCCACCATGATGTGGGGGACCAAAC-3' and 5' -TTACACGCGTGTTAACTTACTTTCCAAGTCGGTTCATCTCTATGTCTGTATACAACTTGTATGTCAAAA- 3 '. The obtained cDNA encoded the full-length HGF sequence, flanked with $M l u I$ sites and fused to a Kozak consensus ribosome binding site at the $\mathrm{N}$ terminus and to oligonucleotides encoding the 11 aa vesicular stomatitis virus glycoprotein $\mathrm{G}$ (VSVG) tag at the $\mathrm{C}$ terminus. The fidelity of the HGF insert was verified by sequencing (MWG Biotech, Ebersberg, Germany). The insert was then ligated into the MluI site of pBI-EGFP (Clontech, Mountain View, CA) to generate the HGF-TREEGFP responder plasmid. MDCK cells expressing the tetracycline transactivator (tTA) under cytomegalovirus promoter (MDCK-Tet-Off cell line; Clontech) were transfected with pBI-HGF-TRE-EGFP plasmid and a blasticidin selection plasmid. Exponentially growing MDCK-tTA cells were seeded $24 \mathrm{~h}$ before DNA transfer on $10 \mathrm{~cm}$ tissue culture dishes and transfected using Lipofectamine 2000 (Invitrogen). Cells were selectively grown in growth media containing $5 \mu \mathrm{g} / \mathrm{ml}$ blasticidin (Sigma-Aldrich) for 2 weeks. Different resistant clones were picked by selective trypsinization and checked for inducible expression of EGFP reporter gene and HGF by in vivo imaging of EGFP and scatter assay of conditioned medium, respectively (see Fig. 8). Clone n.1, which expresses high levels of EGFP- and HGF-transfected protein, was selected for this study.

Tet-Off cells were grown in monolayer at $37^{\circ} \mathrm{C}$ in $5 \% \mathrm{CO}_{2}$, in DMEM (Invitrogen) containing $4500 \mathrm{mg}$ of glucose, $1 \mathrm{~mm}$ sodium pyruvate, 2 $\mathrm{mm}$ glutamine, $100 \mu \mathrm{g} / \mathrm{ml}$ streptomycin, and $100 \mathrm{U} / \mathrm{ml}$ penicillin, and supplemented with $10 \%$ fetal bovine serum (FBS; Invitrogen). To turn off EGFP and HGF expression, Dox $(1 \mu \mathrm{g} / \mathrm{ml})$ was added to the culture medium. Cells within six passages were used throughout the experiments.

\section{Western blot}

For Western blotting analysis, equal amounts of proteins $(100 \mu \mathrm{g})$ were boiled in sample buffer ( $33 \%$ bromphenol blue, $33 \% \beta$-mercaptoethanol, and $33 \%$ glycerol) and subjected to $7 \%$ SDS-PAGE. Proteins were blotted onto Hybond-C Extra membrane (GE Healthcare, Piscataway, NJ). Filters were probed with specific primary antibodies: 1:500 anti-mouse met \#B-2 (Santa Cruz Biotechnology), 1:500 HGF goat antiserum (R \& D Systems), 1:1000 P5D4 Mab (monoclonal antibody) mouse antiserum raised against the 11 aa $\mathrm{C}$ terminus of VSVG (Crepaldi et al., 1997) to detect HGF protein in lysates from MDCK cells expressing tagged HGF. In the latter case, total extracts were run under nonreducing conditions. Immunoblots were developed with an enhanced chemiluminescence kit, ECL (GE Healthcare).

\section{Cell scattering assay}

A classic scatter assay, using Met-expressing MDCK epithelial cells (Stoker et al., 1987; Montesano et al., 1991; Powell et al., 2001), was used to determine whether culture medium conditioned (CM) by nasal explants or Tet-Off cells contained functional HGF. MDCK cells were cultured in the same medium used for transfected cells, supplemented with $5 \%$ FBS (Invitrogen). MDCK cells (8000) were plated onto glass coverslips. The following day, discrete colonies were formed and then treated with known concentrations of HGF or CM (diluted 1:1 in fresh culture medium) collected from nasal explants at 3 div (medium conditioned for $3 \mathrm{~d}$ ) or from Tet-Off cells cultured in the absence or presence of Dox (medium conditioned for 5-7 d). In a subset of experiments, a blockingfunction HGF antibody was added $(5 \mu \mathrm{g} / \mathrm{ml})$. Twenty-four hours later, the MDCK cells were washed in PBS, fixed with $4 \%$ formaldehyde, and stained either by the nuclear cell dye 4,6-diamidino-2-phenylindole (DAPI) or by crystal violet. Images were taken under an Olympus IX50 inverted microscope (Olympus Optical) equipped with a CCD camera CoolSNAP-Pro (Media Cybernetics). Quantitative analysis of the scatter response was performed on digitized images that were overlaid on circles with a diameter of $80 \mu \mathrm{m}$ (see Fig. $5 E$ ). MDCK cells were counted within each circle superimposed on areas in which cells were detectable. In general, the number of cells within these counting frames decreases as a function of cell scatter. Values were reported as the mean \pm SEM. ANOVA followed by Fisher's LSD post hoc analysis was used to compare groups $(p<0.001)$.

\section{Tet-Off cell aggregates}

Tet-Off cells were collected by trypsinization, resuspended in $20 \mu \mathrm{l}$ of growth-factor free Matrigel (BD Biosciences, San Jose, CA) diluted 1:1 with the culture medium and seeded in $20 \mu$ l drops of this solution (200,000 cells for both cell lines, with or without Dox) on the lid of a culture dish. The lid was then turned upside down and incubated at $37^{\circ} \mathrm{C}$ for $10-20 \mathrm{~min}$. As the droplets of cell aggregates were set, they were cut into four pieces (each one containing $\sim 50,000$ cells) with a sterile blade.

\section{Embryonic slice cultures}

Timed pregnant CD-1 mice (Charles River Laboratories) were harvested at E12.5 to generate whole-head organotypic slice cultures following the procedures described previously (Tobet et al., 1996; Bless et al., 2000). Briefly, embryonic heads were embedded in $8 \%$ low-gelling-temperature agarose (type VIIa; Sigma-Aldrich), and parasagittal sections were cut at $300 \mu \mathrm{m}$ using a vibratome and placed into Petri dishes containing icecold dissection medium (Leibovitz's L-15; pH 7.4; Invitrogen). These slices were moved carefully to avoid any torsion, stretch, or compression trauma, which may compromise the migration of GnRH-1 neurons in vitro.

Day 0. E12.5 organotypic slices went through all of the steps described above until the point of plating. At this point, the tissue was fixed with $4 \%$ PFA and stained for GnRH-1 as described above.

Day 1. All slices that were subjected to functional treatments were maintained in culture for $24 \mathrm{~h}$. Organotypic slices were plated onto 30 $\mathrm{mm}$ Millicell inserts (Millipore) coated with a thin layer of growth factorfree Matrigel (BD Biosciences). The inserts were placed into dishes containing $2 \mathrm{ml}$ of culture medium. This medium was partially removed from the wells, such that only a thin layer of liquid remained covering each slice. The slices were maintained in a humidified incubator $\left(37^{\circ} \mathrm{C}\right)$ for $1 \mathrm{~d}$. The slice culture medium consisted of Neurobasal medium (Invitrogen) supplemented with B27 supplement (Invitrogen), $0.5 \mathrm{~mm}$ glutamine (Invitrogen), and $25 \mu \mathrm{g} / \mathrm{ml}$ gentamycin (Invitrogen).

Aggregates of Tet-Off cells (50,000 cells) expressing EGFP-HGF (with or without Dox) were placed at the rostral tip of the nasal region at 0 div. After $24 \mathrm{~h}$, organotypic cultures were fixed with $4 \%$ PFA and stained for GnRH-1 as described above. Slices were used for the quantitative analyses if they contained at least $250 \mathrm{GnRH}$-1-immunoreactive (GnRH-1-ir) neurons and if the connection between the nasal compartment and the brain appeared intact.

Data analysis. Quantitative analysis of GnRH-1 neurons was per- 

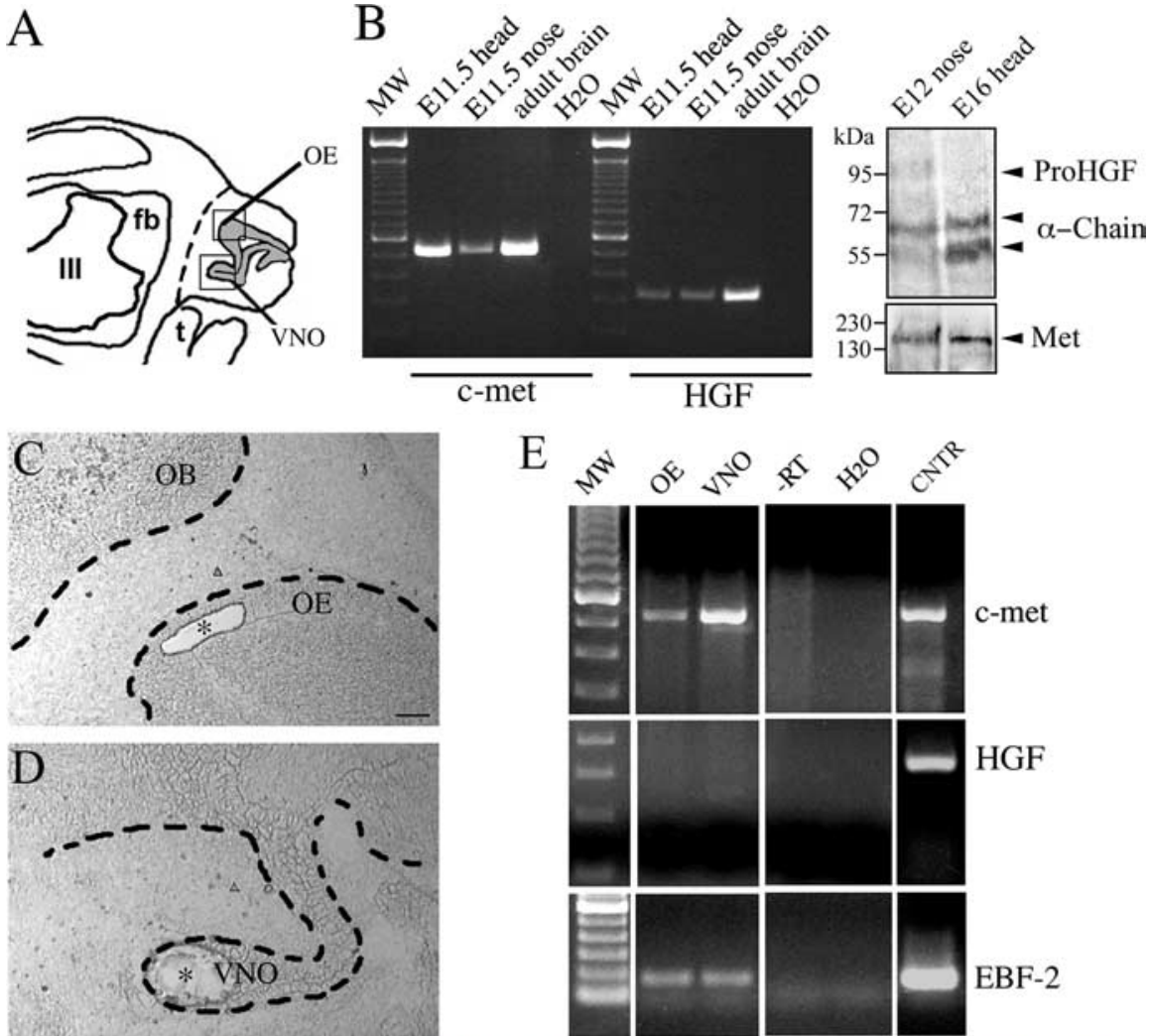

E
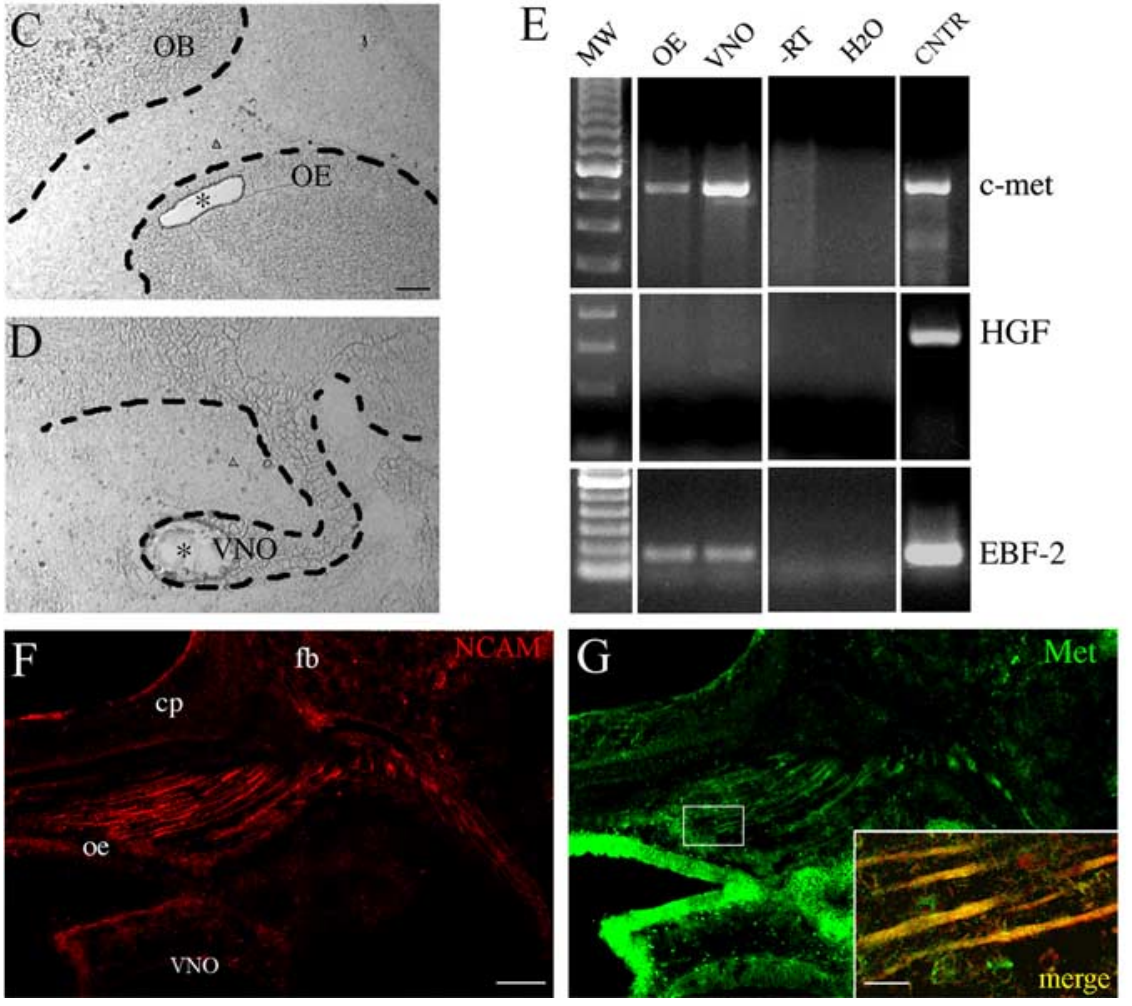

Figure 1. Nasal regions express HGF and its receptor Met during embryonic development. Schematic of an E11.5-E12.5 head [fb, $O E$, presumptive VNO, tongue (t), and third ventricle (III) are depicted]. The dashed line indicates the boundary between nose and brain and represents the region taken for nasal RNA isolation in $\boldsymbol{B}$. $\boldsymbol{B}$, Gel documentation of products produced by RT-PCR amplification using specific primers for c-met and HGF. Total RNA was isolated from nose and whole head at E11.5. Adult brain was used as positive control tissue. Transcripts for both c-met and HGF were detected in all samples but water. Western blot analysis showed that HGF is expressed in its active form in protein extracts of E12 noses as well in whole heads of E16, used as positive control tissue. Western blot was run under reducing conditions. Met expression was also detected in the same samples. $\boldsymbol{C}, \boldsymbol{D}$, Photographs of E14.5 sagittal sections after LCM. Representative pictures show examples of microdissected OE (C) and VNO (D). No other tissue was removed from the nasal section, and the remaining tissue was intact after the capture procedure. $\boldsymbol{E}$, Total RNA isolated from dissected regions was subjected to RT-PCR. A fragment of the expected size (519 bp) was detected for c-met in the OE and in VNO. Expression of the olfactory marker EBF-2 (165 bp) confirmed the morphology of the dissected tissue. PCR using HGF primers showed the expected amplicon (314 bp) in the positive control lane (CNTR; E17.5 whole-embryo extracts) but not in OE or VNO. No PCR product was observed in reactions that omitted either reverse transcriptase or starting material (water). $\boldsymbol{F}, \mathbf{G}$, Sagittal section of an E14.5 mouse nose double stained for NCAM (expressed by olfactory/vomeronasal axons; $\boldsymbol{F}$ ) and Met (G). Met immunoreactivity is distributed in the developing $\mathrm{OE}$ and VNO structures and along the olfactory/vomeronasal fibers. $\boldsymbol{G}$, Inset, Colocalization between the two antigens. MW, Molecular weight; $O B$, olfactory bulb. Scale bars: (in $\boldsymbol{C}$ C, $\boldsymbol{D}, 30 \mu \mathrm{m}$; (in F) F, G, 100 $\mu \mathrm{m} ; \mathbf{G}$, inset, $22 \mu \mathrm{m}$. Asterisks indicate laser-captured areas.

formed as a function of location with GnRH-1 cells assigned to one of two regions (nasal region and CNS). Total number of cells was calculated for each slice and combined to give group means \pm SEM. Given that the total number of GnRH-1 neurons per slice did not change between treatment groups (see Results), GnRH-1 cell distribution is presented as the average percentage of labeled cells located in the nose or in the CNS under different treatment conditions. Where a significant overall oneway ANOVA was found $(p<0.05)$, post hoc comparisons using Fisher's
LSD test were performed to further clarify significant differences between individual treatment groups $(p<0.05)$.

Quantitative analysis of $G n R H-1$ neurons in $t P A^{-1-}: u P A^{-1-}$ mutant animals

Serial sagittal sections ( $30 \mu \mathrm{m}$; four series) from $\mathrm{tPA}^{-1-}: \mathrm{uPA}^{-1-}$ and WT mice $(n=3$ for each group) were cut and labeled for GnRH-1 as described above (GnRH-1 immunoreactivity visualized using DAB substrate). Total numbers of GnRH-1 cells were calculated in each brain and combined to give group means \pm SEM. Data for GnRH-1 cell number between WT and knock-out animals were compared by one-way ANOVA followed by a Fisher's LSD post hoc test. ANOVA data were considered significantly different if $p<0.05$.

\section{Results}

HGF/Met expression in the developing nasal regions

To identify whether Met and HGF were expressed prenatally in nasal regions, nose tissue was removed at E11.5, when GnRH-1 neurons are in the presumptive $\mathrm{VNO}$, and RT-PCR experiments were performed (Fig. 1 $A, B$ ). Both c-met and HGF transcripts were detected in all samples (E11.5 head, E11.5 nose, and adult brain) but water. Western blot analysis was used to document protein expression in embryonic nose tissues (Fig. $1 B$, right). HGF is initially biosynthesized and secreted in a biologically inactive single-chain form (pro-HGF; $\sim 100 \mathrm{kDa}$ ) and is subsequently activated by specific serine proteases into an $\alpha$-chain $(69 \mathrm{kDa})$ and a $\beta$-chain $(34 \mathrm{kDa})$ form containing a total of five glycosylation sites (Nakamura et al., 1989). E12 nose tissues and E16 head extracts (positive control) showed distinct bands corresponding to the $\alpha$-chain (Fig. $1 B$, right). Protein bands of $\alpha$-chain were not single, showing that these proteins were glycosylated heterogeneously. The top band corresponds to the glycosylated form $(69 \mathrm{kDa})$, whereas the bottom band represents the nonglycosylated $\alpha$-chain $(53 \mathrm{kDa})$. E12 nose protein extracts contained a barely detectable band of inactive single-chain HGF (100 kDa), indicating that most HGF in these tissues is the activated form. A $145 \mathrm{kDa}$ Metimmunoreactive band was also evident in the same protein extracts (Fig. $1 B$, right). These results indicate that at E12, both active HGF and its receptor are expressed in the nasal compartment.

To determine the expression of HGF and c-met transcripts in more defined regions of the nasal compartment, LCM was used. Single punches from olfactory epithelium (OE) and VNO were removed at E14.5, and RT-PCR experiments were performed (Fig. 1C-E). This embryonic age corresponds to a stage of robust axonal outgrowth from the OE to the developing olfactory bulb. 
After reverse transcription of the mRNA, PCR with specific primers for $\beta$-tubulin (positive control) and the olfactory marker Olf/EBF-2 was performed (Fig. $1 E)$. A 158 bp band corresponding to $\beta$-tubulin (data not shown) and a $165 \mathrm{bp}$ band corresponding to EBF-2 product were detected in both OE and VNO, supporting the olfactory nature of the lasercaptured tissues (Wang et al., 1997). Products for c-met were found in the $\mathrm{OE}$ as well as in the VNO section, with a stronger expression in the latter tissue (Fig. $1 E$ ). HGF transcript was not detected in the $\mathrm{OE}$ and VNO regions, whereas a specific band of correct size was found in the control lane (E17.5 whole-embryo extracts) (Fig. 1E). These LCM RT-PCR data are in agreement with previous in situ hybridization studies showing c-met and HGF mRNAs in the developing murine $\mathrm{OE}$ and in the surrounding nasal mesenchyme, respectively (Thewke and Seeds, 1996).

To determine whether Met protein was expressed by the developing olfactory axons, double-label immunofluorescence was performed for Met and NCAM, a marker of the olfactory/vomeronasal system (Calof and Chikaraishi, 1989; Miragall et al., 1989). Met and NCAM expressions overlapped on fibers emerging from the VNO at E14.5, as shown by single confocal planes (Fig. $1 F, G$, inset), and were coexpressed in olfactory/vomeronasal axon bundles from the nasal tract to the medial surface of the forebrain throughout the analyzed stages (E12.5-E17.5). Because of low signal-to-noise levels in brain, we were unable to detect specific immunoreactivity for Met along the caudal nerve that GnRH-1 cells follow into the ventral forebrain (Yoshida et al., 1995).

\section{Migrating GnRH-1 neurons express Met}

Immunohistochemistry indicated Met protein expression in the presumptive VNO epithelium as well as in cells migrating out of this structure into the nasal mesenchyme (Fig. $2 A$, arrows) and along vomeronasal fibers of E12.5 embryos (Fig. 2A, arrowheads). To establish whether Met-positive cells were GnRH-1migrating neurons, double immunohistochemical stainings were performed. Double-labeling experiments for GnRH-1 and Met indicated that, at E12.5 (Fig. 2 B, C) and E14.5 (data not shown), the majority of GnRH-1 neurons were Met immunopositive (Fig. $2 B, C$, arrows), as revealed by merged single confocal planes (Fig. $2 C$, inset, arrows). Once within the brain, it was difficult to determine whether GnRH-1 neurons maintained Met expression, because of the high level of expression of this receptor in other CNS cells (data not shown). However, at postnatal day 10, Met expression was broadly downregulated throughout the brain, although there was evidence of discrete Met staining within the hypothalamus (Fig. 2 D, arrowheads). This corresponds to a stage when the GnRH-1 migratory process is over. Double labeling for GnRH-1 (Fig. 2D-F, arrows) and Met (arrowheads) at PN10 revealed no coexpression between the two antigens, as shown by single confocal planes (Fig. $2 E, F$ ). Thus, Met immunoreactivity is associated with migrating GnRH-1 neurons, being downregulated once these cells complete their migration.

\section{HGF/Met expression in nasal explants}

The HGF/Met expression pattern observed in nasal regions during development together with results from previous studies (Sonnenberg et al., 1993; Thewke and Seeds, 1996; Powell et al., 2001) suggest that HGF may have a role in regulating the GnRH-1 migratory process. In this context, nasal explants represent a valuable tool to separate spatial from temporal cues and focus on the properties of GnRH-1 neurons by controlling extracellular influences (Fueshko and Wray, 1994; Giacobini et al., 2004). It has been shown previously that the migrational pattern of GnRH-1 neurons observed in vivo reproducibly occurs in nasal explants in vitro; with a shift in location of the GnRH-1 cell population from the olfactory pit epithelia (OPEs) to the edge of the main tissue mass occurring from 1 to 3 div and continuing to more distant sites from 3 to 7 div (Fueshko and Wray, 1994).

To use nasal explants for functional studies, we first verified that this system retained expression of HGF and its receptor similar to the in vivo expression pattern. At 3 div, the majority of GnRH-1 neurons are located in the inner tissue mass of the explant, but some have started to migrate out into the periphery of the explant (Fig. 3B, arrows). At this stage, HGF immunoreactiv- 

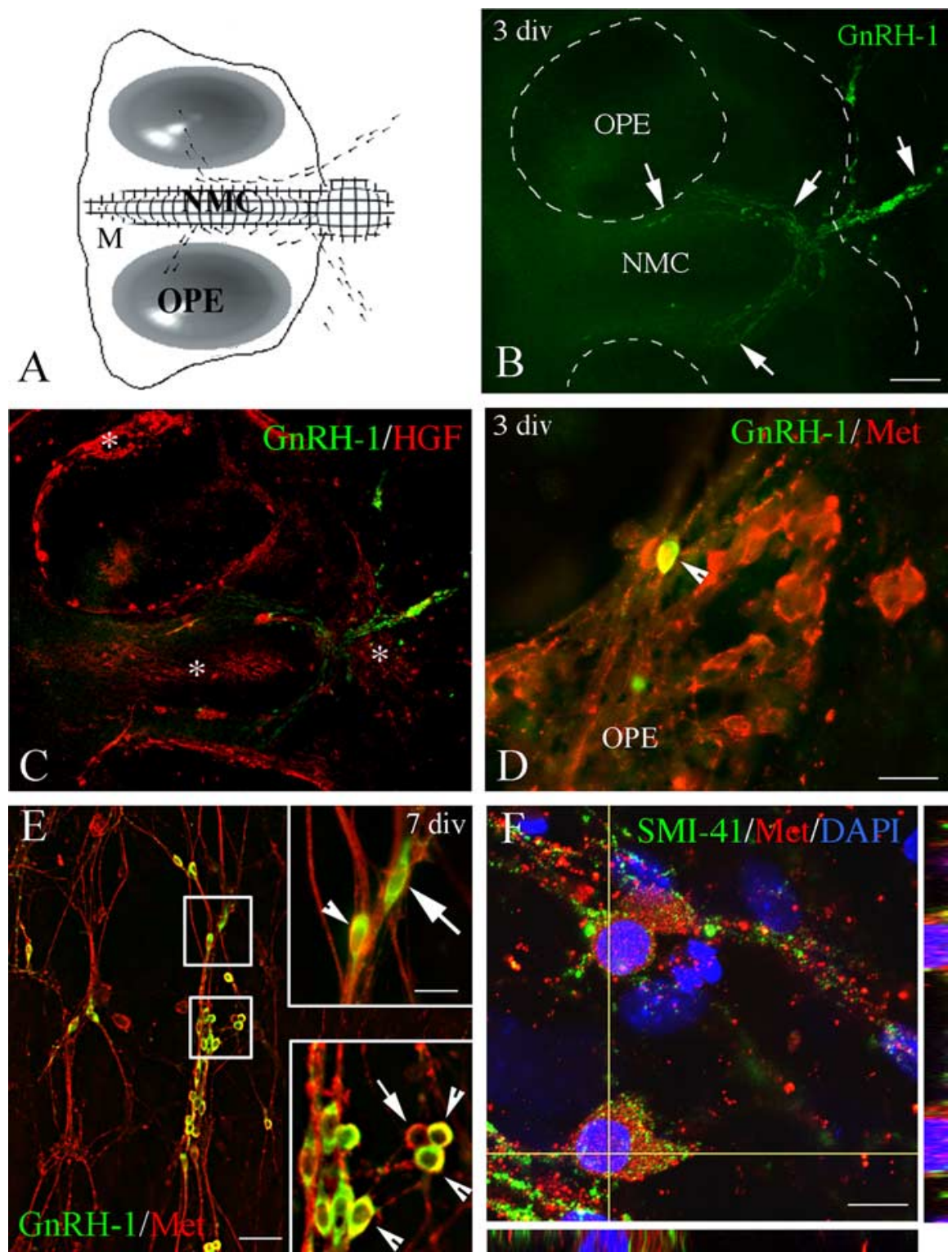

Figure 3. HGF and Met expression in nasal explants mimics expression in vivo. $\boldsymbol{A}$, Schematic of a nasal explant removed from an E11.5 mouse and maintained in serum-free media for $7 \mathrm{~d}$. Ovals represent OPEs; in the center is the nasal midline cartilage (NMC) and surrounding mesenchyme (M). GnRH-1 neurons (dots) migrate from OPE following olfactory axons to the midline and off the explant into the periphery. $\boldsymbol{B}, \boldsymbol{C}$, Double immunofluorescence was performed using antibodies to $\mathrm{GnRH}-1$ (green; $\boldsymbol{B}, \boldsymbol{C}$ ) and $\mathrm{HGF}$ (red; $\boldsymbol{C}$ ) at 3 div. Note that $\mathrm{GnRH}-1$ neurons at this stage migrate off the OPE through the nasal mesenchyme and emerge into the periphery of the explant. Dashed lines indicate the border between the inner tissue mass and the periphery (B). $\boldsymbol{C}, \mathrm{HGF}$ is expressed in the submucosa lining the OPE structures, in the nasal midline cartilage, and in the $n / f b J$ mesenchyme (asterisks). $\boldsymbol{D}, 0 \mathrm{PE}$ in inner tissue mass of a 3 div nasal explant stained for GnRH-1 (green) and Met (red). Met was robustly expressed in the olfactory epithelium. In addition, a GnRH-1 neuron migrating out of the OPE clearly expressed Met (arrowhead). $\boldsymbol{E}$, At 7 div, a large population of GnRH-1 neurons is located in the periphery of the explant. The majority of GnRH-1 neurons coexpressed Met receptor (bottom inset, arrowheads). Few GnRH-1-positive/Met-negative cells were also detected (top inset, arrow), as well as migrating cells, which were positive for Met but not for GnRH-1 (bottom inset, arrow). Met immunoreactivity was also evident along the olfactory axon network. F, Nasal explant at 7 div triple stained for the amidated form of GnRH-1 (antibody SMI41; green), Met (red), and DAPI (nuclear dye; blue). Three-dimensionally reconstructed GnRH-1-positive cells colabeled with Met are shown. Reconstructed orthogonal projections are presented as viewed in the $x-z$ (bottom) and $y-z$ (right) planes. Scale bars: (in $\boldsymbol{B}) \boldsymbol{B}, \boldsymbol{C}$, $100 \mu \mathrm{m} ; \boldsymbol{D}, 20 \mu \mathrm{m} ; \boldsymbol{E}, 30 \mu \mathrm{m} ; \boldsymbol{E}$, insets, $10 \mu \mathrm{m} ; \boldsymbol{F}, 4 \mu \mathrm{m}$.

ity was robustly expressed in the submucosa adjacent to the OPE, in the midline cartilage, and in mesenchymal cells located at the border between the inner tissue mass and the periphery, coinciding with the site at which GnRH-1 neurons and olfactory axons exit (Fig. 3C, asterisks). This latter region corresponds to the frontonasal mesenchyme, also known as nasal/forebrain junction $(\mathrm{n} / \mathrm{fb} \mathrm{J})$ in vivo. The expression pattern of Met receptor was then examined at the same in vitro stage. Met coexpressed with migrating GnRH-1 neurons as well as with the olfactory neurons in the OPE (Fig. 3D, arrowhead). At 7 div, GnRH-1 neurons are located in the periphery of nasal explants in close association with the olfactory fibers. At this stage, the majority of GnRH-1 neurons expressed Met (Fig. 3E, F, arrowheads), although some Met-positive/ GnRH-1-negative cells were detected as well (Fig. 3E, arrows). In addition, olfactory axons, along which GnRH-1 neurons migrated, exhibited Met staining (Fig. 3E). Hence, consistent with in vivo results, Met receptor demarcated the olfactory system and the migrating GnRH-1 cell population.

\section{tPA is expressed in migrating GnRH-1 neurons in vitro}

tPA and uPA are serine proteases that, in addition to other proteases related to blood coagulation factor XII, have been shown to cleave and activate pro-HGF (Mars et al., 1993). Moreover, PAs expression is most pronounced during cell migration and axonal outgrowth processes in the developing nervous system (Seeds et al., 1997). Thus, tPA and uPA expression by GnRH-1 neurons was evaluated in vitro.

Single GnRH-1 cells were removed from nasal explants at 4.5 and $28 \mathrm{div}$ (Fig. $4 A-C$, arrows), two in vitro stages representative of GnRH-1 cells during migratory and postmigratory phases, respectively (Fueshko and Wray, 1994). cDNA pools were examined for tPA and uPA transcripts by single-cell RT-PCR. At 4.5 div, the majority of GnRH-1 cells (four of five) expressed tPA but not uPA transcripts. By 28 div, all GnRH-1 neurons $(n=5)$ were negative for both transcripts (Fig. 4D). Double immunofluorescence for $\mathrm{GnRH}-1$ and $\mathrm{tPA}$ was performed in nasal explants at $4.5 \mathrm{div}$ (Fig. $4 E$ ). These experiments revealed coexpression of the antigens (Fig. 4E, arrows, inset) as well as expression of tPA along olfactory axons, confirming previous in situ hybridization studies (Thewke and Seeds, 1996). Thus, immunocytochemical experiments confirmed single-cell PCR results showing that tPA is expressed in GnRH-1 cells in a temporal window limited to the neuronal migratory process.

Functional analyses

Nasal explants release bioactive HGF in the culture medium The expression analyses demonstrate that HGF protein is present in nasal regions both in vivo and in vitro with a temporal and 
spatial pattern to impact GnRH-1/olfactory system development. The form of HGF observed in E12 noses by Western blots is indicative of a biologically active protein. To test whether the embryonic nasal region is able to release functional HGF, nasal explant CM was collected, and a typical scatter assay was performed, taking advantage of the Met-expressing MDCK cell line. In the absence of HGF, these cells grow in compact colonies (Fig. $5 A$, inset, arrows). The addition of 10 $\mathrm{ng} / \mathrm{ml} \mathrm{HGF}$ for $48 \mathrm{~h}$ to MDCK cultures induced a typical change in morphology of MDCK cells and a scatter response resulting in cell dispersion (Fig. 5B, inset, arrows). CM from 3 div nasal explants also enhanced migration capacity (Fig. 5C), which was blocked by the addition of HGF-neutralizing antibody $(5 \mu \mathrm{g} / \mathrm{ml})$ (Fig. 5D). The scatter response was quantified by measuring the number of MDCK cells contained within each counting frame (see Materials and Methods) (Fig. $5 E$, arrows). This number decreases as a function of cell dispersion after increased migratory activity. Quantification of the scatter response showed more than a 50\% reduction in the cell number contained within each counting frame in HGF- and CM-treated groups compared with control conditions (Fig. 5E).

\section{Anti-HGF disrupts GnRH-1 neuronal migration and olfactory axon outgrowth}

To determine the role of endogenous HGF on GnRH-1/olfactory system development, the explants were treated with antiHGF $(5 \mu \mathrm{g} / \mathrm{ml})$. The same concentration of this antibody has been used in previous studies to neutralize the activity of HGF (Powell et al., 2001; Giacobini et al., 2002). Nasal explants were treated from 3 to 6 div, a temporal window characterized by massive olfactory axonal growth and GnRH-1 neuronal migration from the inner tissue mass to the periphery of the explant (Fueshko and Wray, 1994). Nasal explants were fixed at $7 \mathrm{div}$ and stained for GnRH-1 and peripherin, which stains the olfactory system (Fig. 6A). No significant differences were found in total number of GnRH-1 cells inside the inner tissue mass (control, $64 \pm 9$; $n=18$; anti-HGF treatment, $74 \pm 9 ; n=20$ ) or in the periphery of the explant (control, $176 \pm 22 ; n=20$; anti-HGF treatment, $150 \pm 18 ; n=21$ ). No changes in GnRH-1 cell number after treatment suggests that mitogenic and survival effects of HGF on GnRH-1 neurons are unlikely. However, application of antiHGF severely stunted the migration of

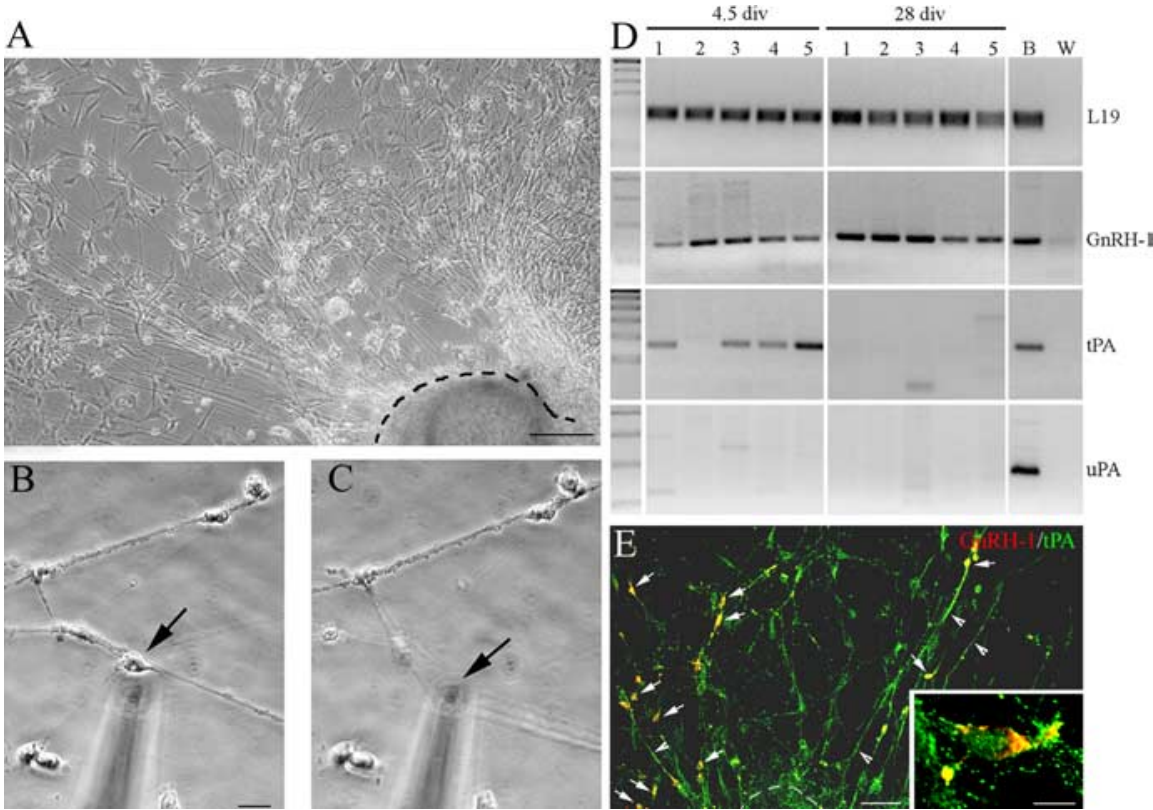

Figure 4. Primary GnRH-1 neurons express tPA during their migration. $A$, Photomicrograph of a nasal explant maintained for 4.5 div. Numerous GnRH-1-like neurons (phase-bright cells) can be seen in the periphery of the explant. The dashed line delineates the main nasal tissue from the periphery of the explant. Bipolar $\mathrm{GnRH}$-1-like cells in the periphery of the explant are identified in situ ( $\boldsymbol{B}$, arrow) and removed ( $\boldsymbol{C}$, arrow) with a microcapillary pipette. $\boldsymbol{D}$, Representative gel of PCR products from single-cell RT-PCR performed on $\mathrm{GnRH}-1$ cells ( 4.5 and $28 \mathrm{div}$ ) extracted from the explant periphery. Products produced by PCR amplification using L19-, GnRH-1-, tPA-, and uPA-specific primers. tPA transcript was detected in primary GnRH-1 neurons at 4.5 div (80\%) but not at 28 div. uPA transcript was not detected in GnRH-1 neurons at either 4.5 or 28 div. No specific band was detected in water (W). B, E17.5 brain, positive control. $\boldsymbol{E}$, Nasal explant at 4.5 div double stained for GnRH-1 (red; arrows) and tPA (green). Inset, A single confocal plane showing a GnRH-1-positive cell colabeled with $\mathrm{tPA}$. Scale bars: $\boldsymbol{A}, 100 \mu \mathrm{m}$; (in $\boldsymbol{B}) \boldsymbol{B}, \boldsymbol{C}, 10$ $\mu \mathrm{m} ; \boldsymbol{E}, 50 \mu \mathrm{m} ; \boldsymbol{E}$, inset, $5 \mu \mathrm{m}$.
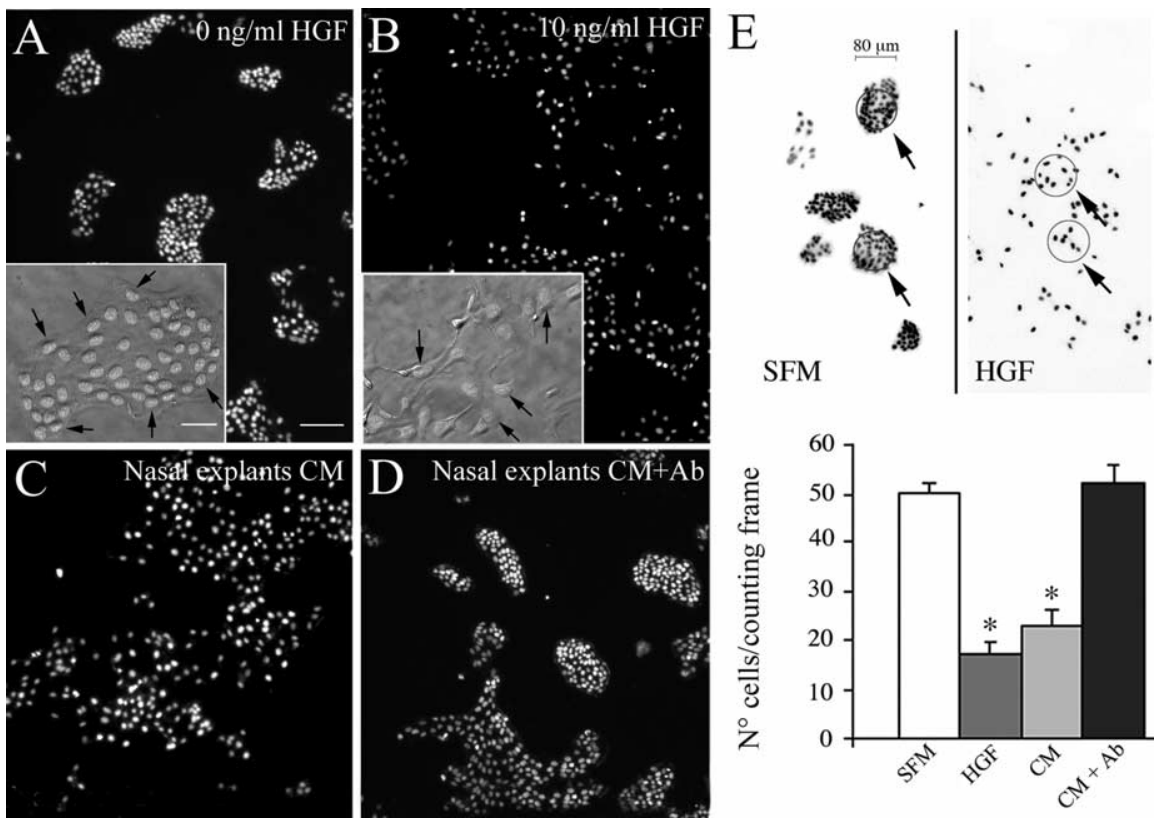

Figure 5. Nasal explants release functional HGF. A-D, Images show MDCK cells that were plated at identical densities and stained with nuclear dye DAPI (white). $\boldsymbol{A}$, In SFM conditions, MDCK cells organized in typical colonies (inset; DAPI and bright field; arrows point to individual cells in a cluster). $\boldsymbol{B}$, In the presence of $10 \mathrm{ng} / \mathrm{ml} \mathrm{HGF,} \mathrm{MDCK}$ cells dispersed (scatter) and moved away from each other (inset). Conditioned medium from 3 div nasal explants induced scatter response of MDCK cells $(\boldsymbol{C})$, which was prevented by the addition of HGF-neutralizing antibody (D). $\boldsymbol{E}$, Quantitative analysis of the scatter response was performed on digitized images that were overlaid on circles (counting frames) with a diameter of $80 \mu \mathrm{m}$ (see Materials and Methods). The number (No) of cells within the counting frames decreases as a function of cell-scatter response $[n=4$ wells counted for SFM-and HGF-treated group; $n=3$ wells counted for $C M$ and $C M$ plus antibody $(C M+A b)$ groups; asterisks indicate statistical differences versus SFM and CM $+A b$ conditions; $p<0.001$ ]. Scale bars: (in $\boldsymbol{A}) \boldsymbol{A}-\boldsymbol{D}, 80 \mu \mathrm{m}$; (in $\boldsymbol{A}$, inset) $\boldsymbol{A}, \boldsymbol{B}$, insets, $24 \mu \mathrm{m}$. 

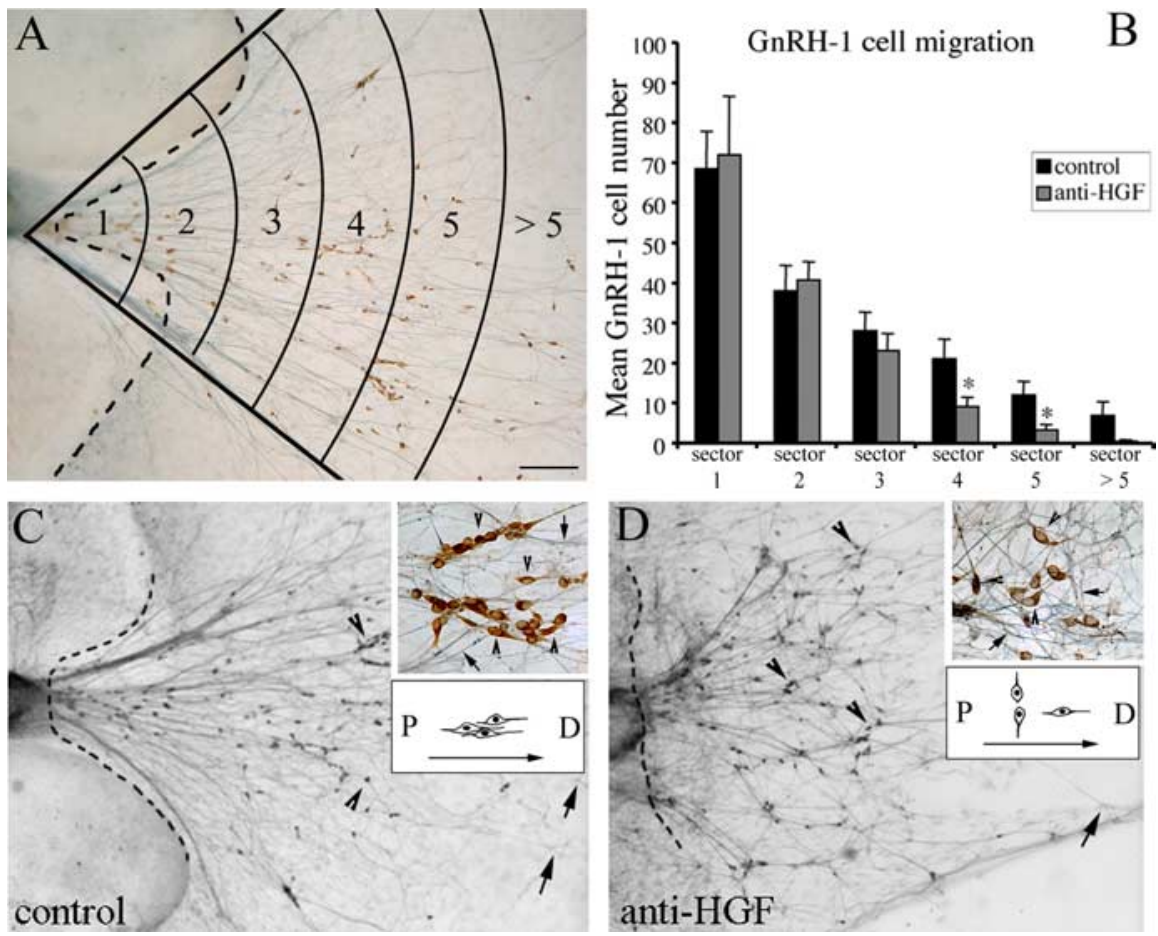

Figure 6. Neutralization of endogenous HGF alters GnRH-1 cell motility and olfactory axon outgrowth. $\boldsymbol{A}$, Photomicrograph of nasal explant immunocytochemically labeled for $\mathrm{GnRH}-1$ (brown) and peripherin (blue) at 7 div. Images were digitized and overlaid on a calibration meter composed of concentric arcs. B, Quantitative analysis of GnRH-1 cell distribution in the periphery of the explant after anti-HGF treatment. Fewer GnRH-1 neurons were located in the farthest zones of the anti-HGF-treated explants compared with controls $\left(0.6-1 \mathrm{~mm}\right.$ away from the border of the explant; ${ }^{*} p<0.001 ; n=20$ and 21 for control and anti-HGF-treated groups, respectively), whereas there was a concomitant accumulation of GnRH-1 cells closer to the explant tissue mass. C, D, Photomicrograph of nasal explants immunocytochemically labeled for GnRH-1 (arrowheads) and peripherin (arrows) at 7 div in control conditions $(\boldsymbol{C}$ ) and after anti-HGF treatment (D). Anti-HGF treatment prevented GnRH-1 cells and olfactory fibers from moving into the periphery but stayed closer to the border of the explant tissue mass. After treatment, GnRH-1 cells displayed an atypical migratory behavior, losing the proximal (P)-to-distal (D) orientation detected in control explants, and the olfactory fiber network also appeared highly disorganized ( $\boldsymbol{C}$ and $\boldsymbol{D}$, insets and schematics). The dashed lines indicate the border of the explant tissue mass. Scale bar (in $\boldsymbol{A}$ ): $\boldsymbol{A}, \boldsymbol{C}, \boldsymbol{D}, 200 \mu \mathrm{m} ; \boldsymbol{C}, \boldsymbol{D}$, insets, $20 \mu \mathrm{m}$.

GnRH-1 cells (Fig. 6B-D, arrowheads, insets) and the peripherin-fiber network in the periphery of the explant (Fig. $6 C, D$, arrows, insets). Quantitative assessment of olfactory fiber outgrowth revealed a significant reduction in the maximum distance from the border of the explant after treatment with antiHGF ( $p<0.001$; control, $1188 \pm 47 \mu \mathrm{m} ; n=17$; anti-HGF treatment, $996 \pm 95 \mu \mathrm{m} ; n=16)$. The complex nature of the fiber network prevented quantification of individual fiber lengths. Therefore, the observed reduced distance of the peripherinpositive fiber bundles could be the result of a defect in olfactory axon elongation or of an altered orientation of the olfactory axons.

For GnRH-1 cell migrational measurements, a caliber with a series of concentric arcs separated by a uniform distance $(200$ $\mu \mathrm{m})$ was overlaid on the digitized image, and the number of cells in each zone was counted (Fig. 6A). In addition to changes in olfactory axons, GnRH-1 neurons were closer to the border of the explant in the anti-HGF treated group compared with controls (Fig. $6 B-D)(p<0.005)$. In control explants, $14 \%$ of the entire GnRH-1 cell population was dispersed beyond zone 4 (>600 $\mu \mathrm{m}$ from the border of the explant tissue mass), whereas when explants received anti-HGF, only $6 \%$ of GnRH-1 neurons migrated $>600 \mu \mathrm{m}$ into the periphery. In treated explants, GnRH-1 neurons also displayed an abnormal migratory behavior. In control conditions, the majority of migrating cells were uniformly ori- ented in a proximal-to-distal direction (Fig. 6C, inset), whereas in the presence of HGF antibody, such polarized direction was lost, and GnRH-1 neurons orientation appeared more random (Fig. 6D, inset). Although "randomly" oriented, the migrating neurons maintained contact with peripherin-positive fibers, which also appeared more entwined and less directionally oriented after anti-HGF treatment (Fig. 6C,D). Thus, we were unable to determine whether the loss of orientation of GnRH-1 neurons was attributable to cellautonomous mechanisms or instead directly dependent on altered outgrowth of olfactory axons.

\section{Exogenous HGF increases GnRH-1 cell migration in nasal explants}

We next evaluated the effect of exogenous HGF on GnRH-1 cell migration and/or on olfactory axon outgrowth. HGF treatment did not affect the total number of GnRH-1 neurons compared with controls (control, $221 \pm 46 ; n=11 ;$ HGF-treated, $204 \pm 19 ;$ $n=10$ ). However, a significant shift in the location of GnRH-1 neurons was noted in HGF-treated cultures (Fig. 7) $(p<0.001)$. In this group, $21 \%$ of GnRH-1 neurons in the periphery of the explant migrated beyond zone 5 ( $>800 \mu \mathrm{m}$ from the edge of the main tissue mass), compared with controls, which displayed only $8 \%$ of the GnRH-1 population in this same compartment. To determine whether HGF had an effect on olfactory axon outgrowth as well, the mean maximum network outgrowth of peripherin fibers was analyzed. Quantitative analysis revealed that the extent of fiber outgrowth was similar among HGF-treated and control explants (control, olfactory axon outgrowth: $1215 \pm 57 \mu \mathrm{m} ; n=11$; HGF-treated, olfactory axon outgrowth: $1292 \pm 48 ; n=10)$, and directionality was maintained in all explant groups (data not shown).

\section{HGF is a guidance signal for migrating GnRH-1 neurons}

The HGF expression pattern suggests that GnRH-1 neurons may follow this diffusible molecule as they move from the VNO toward the nasal/forebrain junction. If this were the case, then addition of an exogenous source of HGF in a direction opposite to the normal migratory pathway (i.e., the rostral tip of the nose) should disrupt or delay GnRH-1 neuronal migration. To test this hypothesis, functional experiments were performed by coculturing for $24 \mathrm{~h}$ cell aggregates of HGF-transfected cells, together with parasagittal slices of whole heads of E12.5 mice. This embryonic age corresponds to a stage in which GnRH-1 neurons span from the VNO to the nasal/forebrain junction, on their way into the CNS (Wray, 2002).

MDCK EGFP-HGF stable transfectants were generated using the Tet-Off expression system (Gossen and Bujard, 1992). Clones were screened through EGFP imaging (Fig. $8 A$, top left). When cells were cultured in the presence of $1 \mu \mathrm{g} / \mathrm{ml}$ Dox, EGFP and HGF expressions were turned off (Fig. $8 \mathrm{~A}$, top right).

To verify HGF biosynthesis in these cells, total extracts were 
run under nonreducing conditions and immunoblotted with anti-VSVG (Fig. $8 \mathrm{~B}$ ). Tet-Off MDCK cells expressing EGFP and HGF were grown in the absence (lane 1) or presence (lane 2) of Dox. Tet-Off MDCK cells expressing only EGFP were used as negative control (lane 3). Transfected HGF was identified as proHGF inside the cells and was expressed only in the absence of Dox. In addition, the ability to produce and release active HGF in the culture medium was tested by using the scatter assay. CM was collected from Tet-Off cells grown with or without Dox for several days, diluted 1:1 with fresh culture medium, and applied onto MDCK cells (Fig. $8 \mathrm{~A}$, bottom).

HGF-releasing cell aggregates were placed at the tip of the nose (Fig. 9C,D). The mean numbers of cells that were GnRH-1 immunoreactive per slice $( \pm$ SEM) were $273 \pm 21$ (control, 0 div; $n=6$ ), $301 \pm 16$ (control, 1 div, with Dox; $n=6$ ), $285 \pm 19$ (HGF, 1 div, without Dox; $n=4$ ), with no significant difference among groups $(p>0.05)$ (Fig. $9 B)$. The changing positions of GnRH-1-ir neurons from nasal compartment to the CNS between day 0 and day 1 control slices provided evidence of migration in vitro (Fig. 9B). Slices grown for 1 div in the presence of EGFP-HGF cell aggregates silenced with Dox showed a broad distribution of GnRH-1 cells from the nasal compartment (Fig. 9E, arrowheads) to the basal forebrain (Fig. 9E, arrows). GnRH-1 neurons migrating through the nasal mesenchyme displayed a bipolar morphology and were visible as streams of neurons directed toward the cribriform plate (Fig. 9E, inset). At this stage, $32 \%$ of the total GnRH-1 neurons entered the brain (Fig. 9B,E, arrows). In contrast, GnRH-1 cells displayed an atypical migratory behavior when embryonic slices were cocultured with EGFP-HGF-expressing cell aggregates cultured in the absence of Dox (Fig. 9D,F). The vast majority of GnRH-1 neurons (90\%) did not reach the forebrain (Fig. 9B, F, arrowheads), as a result of accumulation in the nasal compartment (Fig. 9F, inset). Significant differences in GnRH-1 cell distribution between groups treated with and without Dox were observed both in the nose and in the CNS $(p<0.05)$.

Intense peripherin immunoreactivity was found on olfactory/vomeronasal axons that crossed the nasal mesenchyme and projected into the forebrain in cultures both with and without Dox (Fig. $9 G, H)$. The olfactory fiber network in the nose as well as in the forebrain did not appear to be disrupted when HGF-releasing cell aggregates were cocultured with embryonic slice cultures (Fig. 9G,H).

\section{Fewer GnRH-1 neurons are present in the tPA/uPA deficient mice}

Early embryonic lethality of met mutants has prevented in vivo studies on these mice to determine the functional role of HGF in GnRH-1 neuron development (Bladt et al., 1995; Schmidt et al., 1995; Uehara et al., 1995). Therefore, we investigated the effect of deletion of tPA and uPA genes on the number of GnRH-1 neurons in adult brains. These serine proteases have been shown to activate the progrowth factor HGF (Mars et al., 1993). Moreover, previous studies showed that mice with combined deficiencies of tPA and uPA are subfertile and display reduced gonadotropin-

\section{GnRH-1 cell migration}

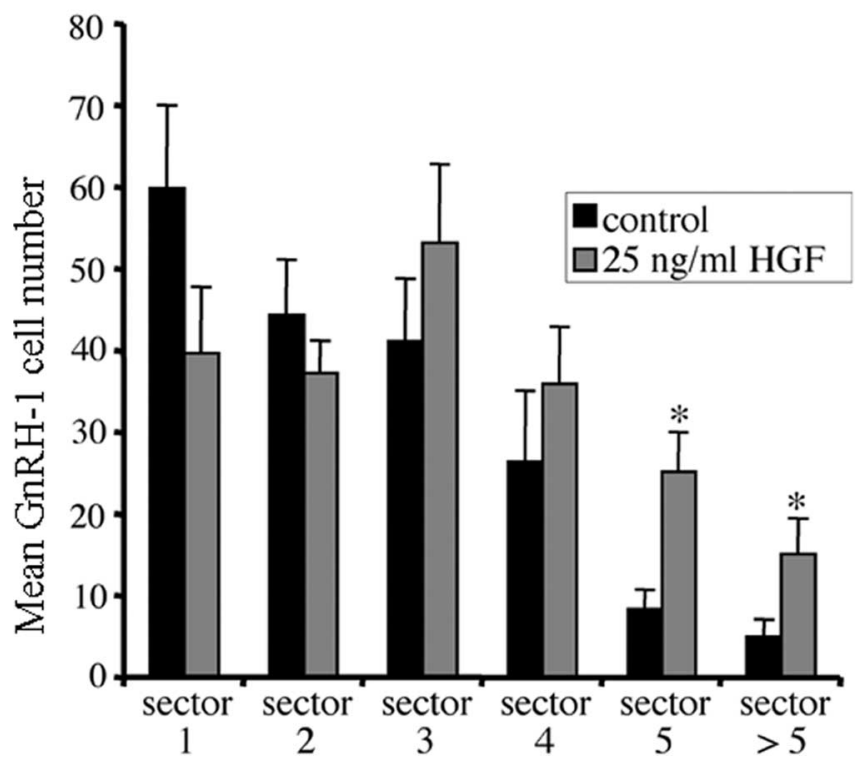

Figure 7. Exogenous HGF increases GnRH-1 cell motility in nasal explants. Quantitative analysis of GnRH-1 cell migration after exogenous application of HGF. The same analysis described in Figure 4 was used in these experiments. HGF ( $25 \mathrm{ng} / \mathrm{ml})$ applied from 3 to 6 div significantly increased, at 7 div, the number of GnRH-1 cells reaching the farthest zones compared with controls ( $n=11$ control; $\left.n=10 \mathrm{HGF-treated} \mathrm{group;}{ }^{*} p<0.001\right)$.
A
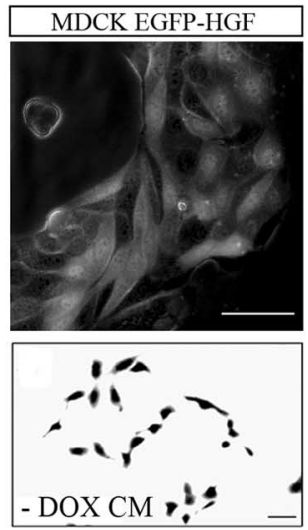

Figure 8. Characterization of the Tet-OffMDCK cell line. $A$, Photomicrograph of the Tet-Off MDCK cell line expressing EGFP and HGF. Note that EGFP is highly expressed by $70-80 \%$ of cells (top left). Cells were cultured in the absence or presence of $1 \mu \mathrm{g} / \mathrm{ml}$ Dox. When cells are shifted to Dox-containing medium, EGFP expression is turned off within $24 \mathrm{~h}$ after the shift (top right). Bottom left, MDCK scatter after a $24 \mathrm{~h}$ incubation with CM collected from Tet-Off MDCK EGFP-HGF stable clone, grown in the absence of Dox. Bottom right, MDCK cells are organized in discrete, compact colonies after exposure of CM collected from with Dox Tet-Off cells. $\boldsymbol{B}$, Western blot analysis for HGF in total extracts of MDCK cells expressing tagged HGF. Total extracts were run under nonreducing conditions and immunoblotted with anti-VSVG antibody. Tet-Off MDCK cells expressing EGFP and HGF were grown in the absence (lane 1) or presence (lane 2) of Dox. Tet-Off MDCK cells expressing only EGFP were used as a negative control (lane 3). Transfected HGF was identified as pro-HGF inside the cells $(100 \mathrm{kDa})$ and was expressed only in the absence of Dox. Scale bars: $A$, top, $5 \mu \mathrm{m} ; A$, bottom, $20 \mu \mathrm{m}$.
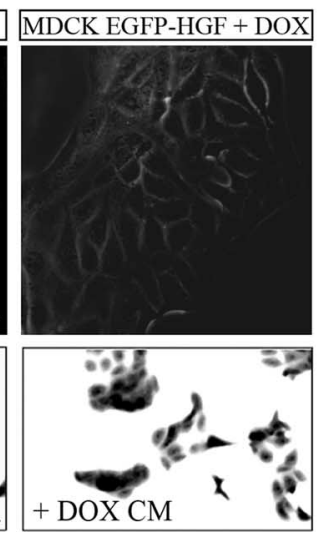

B

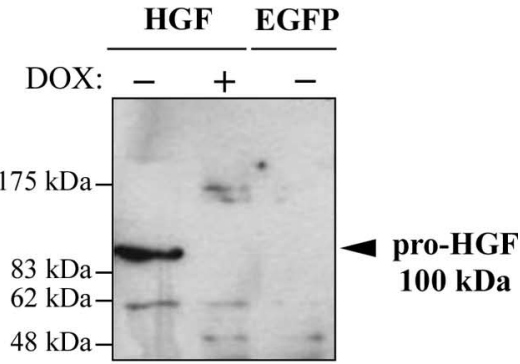

induced ovulation efficiency (Carmeliet et al., 1994; Leonardsson et al., 1995). The total number of GnRH-1 neurons was compared in 60- to 90 -d-old WT male mice $(n=3)$ and age and sex-matched double-KO mice for tPA and uPA genes $(n=3)$. Analysis revealed a significant reduction in GnRH-1 cell number in the brains of mutants compared with WT (WT, $642 \pm 16$; $\left.\mathrm{tPA}^{-l-}: \mathrm{uPA}^{-1-}, 422 \pm 24 ; p<0.001\right)$. A reduction of $\sim 35 \%$ was 
A
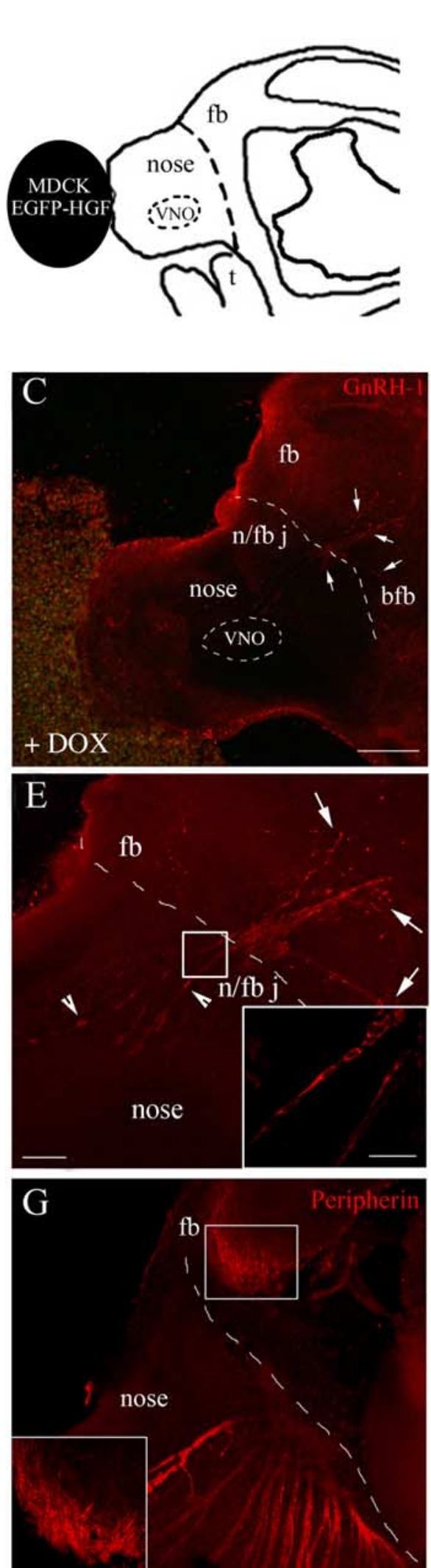

B
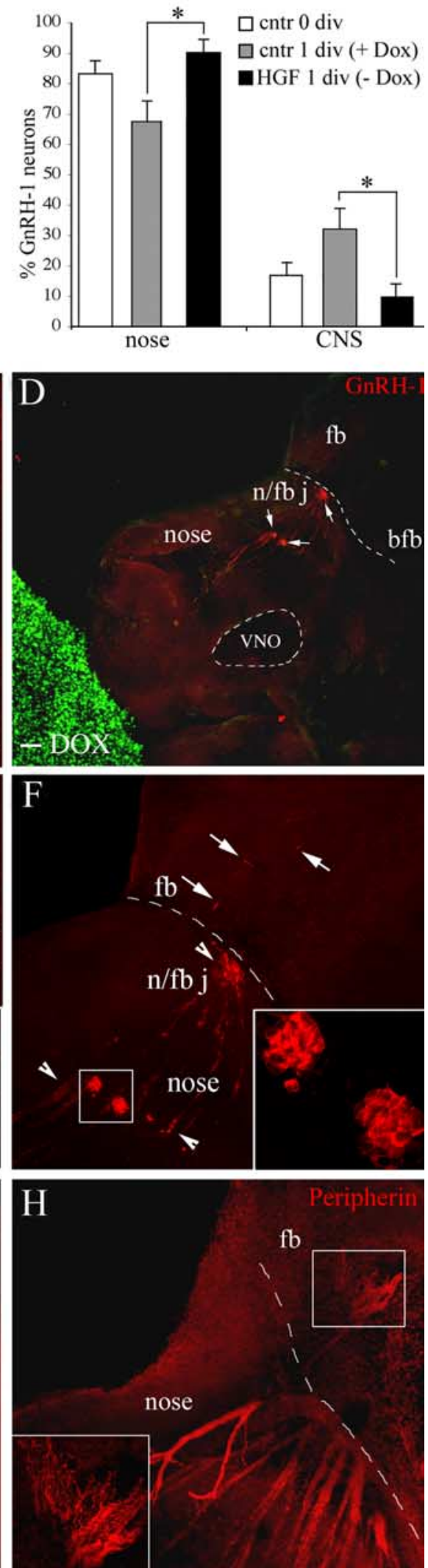

Figure 9. HGF acts as a guidance signal for GnRH-1 neuronal migration during embryogenesis. $A$, Schematic of an E12.5 head slice culture [fb, presumptive VNO, and tongue $(\mathrm{t})$ are depicted]. A dashed line indicates the boundary between nose and brain. Aggregates of Tet-Off cells (black oval), cultured in the presence or absence of Dox, were placed at the rostral tip of the nose of E12.5 slice cultures. B, Quantitative analysis of GnRH-1 cell distribution in the nasal compartment and in the CNS of E12.5 slice cultures at 0 div [control (cntr); $n=6$ ] and grown in vitro for $24 \mathrm{~h}$ with EGFP-HGF cell aggregates (with Dox, $n=6$; without Dox, found in the KO animals. Figure 10, $A$ and $B$, shows representative stainings for GnRH-1 neurons (arrows, single GnRH-1 cells; arrowhead, cluster of GnRH-1 cells) in the diagonal band of Broca $(\mathrm{dbb})$ of the hypothalamus of WT and double-KO mice. At this level, numerous GnRH-1 neurons are normally detected (Fig. 10A). In contrast, few GnRH-1 neurons are detected at this level in $\mathrm{KO}$ mice (Fig. $10 \mathrm{~B}$ ). The median eminence of $\mathrm{tPA}^{-/-} \mathrm{uPA}^{-/-}$ brains was also sparsely innervated by GnRH-1-immunoreactive terminals (Fig. $10 \mathrm{D}$, arrowhead, inset) compared with WT (Fig. 10C, arrowhead, inset).

\section{Discussion}

Development of the olfactory and GnRH-1 neuroendocrine systems is intimately entwined in early embryogenesis (Wray, 2002). The mechanisms directing the initiation of cell migration and olfactory axon extension from nose to forebrain are unclear but likely require specific motogenic and guidance cues. In this report, we show that HGF and Met are expressed in a spatiotemporal pattern to impact GnRH-1/olfactory system development. Functional analysis supports the notion that HGF plays an important role in regulating GnRH-1 neuronal migration across nasal regions toward the CNS during embryogenesis.

Previous studies have shown that c-met and $\mathrm{PPA}$ mRNAs are expressed in olfactory epithelium, whereas HGF transcript localized to the surrounding nasal mesenchyme starting at E11 in mouse (Sonnenberg et al., 1993; Thewke and Seeds, 1996), when

$\leftarrow$

$n=4)$. Analysis of GnRH-1 neurons location revealed an accumulation of cells in the nasal region when organotypic slices were cocultured with HGF-releasing cell aggregates. C, $E$, Normal migrating GnRH-1 neurons in slices cocultured with Tet-Off EGFP-HGF cell line in the presence of Dox. Note that EGFP is turned off in the cell aggregate. GnRH-1-positive cells migrate in chains through the nasal compartment (arrowheads) and enter the brain (arrows). $\boldsymbol{E}$, Inset, A high-power view of typical migratory GnRH-1 neurons crossing the nasal mesenchyme characterized by a bipolar morphology and by a chain-like organization. $\boldsymbol{D}$, When cocultures were performed with transfected cells shifted to a medium without Dox, GnRH-1 neurons accumulate in the nasal region and fail to enter the brain $(\boldsymbol{B}, \boldsymbol{D}, \boldsymbol{F})$. The inset in $\boldsymbol{F}$ shows the abnormal phenotype of GnRH-1 neurons in these cultures. Many cells appear round and lack a leading and a trailing process, typical of migrating cells. $\mathbf{G}, \boldsymbol{H}$, Antibodies to peripherin react with vomeronasal and olfactory axons that extend along the nasal mesenchyme to the forebrain. No difference in the organization of the fiber network was evident among the treatment conditions ( $\boldsymbol{G}$, with Dox; $\boldsymbol{H}$, without Dox). bfb, Basal forebrain. Scale bars: (in C) C, D, $300 \mu \mathrm{m}$; (in $\boldsymbol{E}$ ) $\boldsymbol{E}-\boldsymbol{H}, 150 \mu \mathrm{m}$; (in $\boldsymbol{E}$, inset) $\boldsymbol{E}, \boldsymbol{F}$, insets, $20 \mu \mathrm{m}$. 
the GnRH-1/olfactory systems are in their initial stages of development. Here, biologically active HGF and Met protein expression was documented in nasal regions as early as E12. The majority of GnRH-1 neurons located in the nasal compartment were found to be Met immunopositive with expression correlated with migration. Using RT-PCR, c-met mRNA was detected in laser-captured tissues of OE and VNO at E14.5, confirming previous in situ hybridization studies (Sonnenberg et al., 1993; Thewke and Seeds, 1996). Moreover, immunohistochemistry coupled with confocal microscopy revealed that Met protein is expressed along NCAMpositive olfactory fibers during embryonic development. Thus, the spatiotemporal expression of HGF and Met receptor in nasal regions correlates with migration of GnRH-1 neurons toward the CNS and development of the olfactory sensory system.

To determine the functional role of HGF in the development of the GnRH-1 system, we took advantage of an in vitro model, nasal explants, which has been successfully used for other functional studies (Fueshko et al., 1998; Kramer and Wray, 2000; Giacobini et al., 2004). These explants maintain large numbers of GnRH-1 neurons, migrating in a manner similar to that observed in vivo, as well as directed olfactory axon outgrowth (Fueshko and Wray, 1994). Expression of Met in the olfactory system and in primary GnRH-1 neurons in nasal explants was similar to that observed in vivo. HGF was expressed as early as 3 div, a stage of active cell migration and olfactory axon outgrowth, and the expression paralleled HGF transcript distribution described previously in vivo (Sonnenberg et al., 1993; Thewke and Seeds, 1996). HGF immunoreactivity was observed in the olfactory mucosa surrounding the $\mathrm{OE}$, in the nasal midline cartilage, and in the frontonasal mesenchyme, which is the region apposed to the ventromedial forebrain before dissection. Olfactory pathway development depends on induction between the frontonasal mesenchyme and adjacent olfactory epithelia (LaMantia et al., 2000). Interestingly, HGF mRNA has been shown to be unevenly distributed in the nasal mesenchyme during embryonic development, being expressed in a gradient with higher levels toward the forebrain (Sonnenberg et al., 1993). A similar expression pattern has been shown for SDF-1 in these regions (Schwarting et al., 2006). This transcript is expressed in a steep gradient in the developing nasal mesenchyme, being lower proximal to the VNO and greater at the nasal/forebrain junction. SDF-1 was shown to be important for the migration of GnRH-1 neurons (Toba et al., 2004; Schwarting et al., 2006). Other studies demonstrated that SDF-1 and HGF regulate recruitment of mesenchymal stem cells toward damaged tissues (Ji et al., 2004; Urbanek et al., 2005) and that HGF chemotactic response could be potentiated by SDF-1 (Son et al., 2006). Similarly, muscle progenitor cells migrate toward SDF-1-expressing targets with CXCR4 (CXC receptor 4), the SDF-1 receptor, and Gab1 [Grb2 (growth factor receptor-bound protein 2)-associated binding protein 1], the adaptor molecule that transmits Met signaling, cooperating to control this process (Vasyutina et al., 2005). Thus, we cannot rule out cross talk between the HGF and SDF-1 signaling pathways in regulating directed migration of GnRH-1 neurons from the VNO to the brain.

In addition to Met, primary GnRH-1 neurons express tPA. Interestingly, this expression pattern correlated with migration of these cells, being downregulated in postmigratory GnRH-1 neurons. Previous studies showed that tPA transcript is expressed in migrating neurons crossing the nasal mesenchyme during early stages of embryonic development (Friedman and Seeds, 1994). Here, we suggest that at least part of these cells are GnRH-1 neurons and that these cells display the molecular machinery to activate HGF in the immediate vicinity of its c-met receptor, thus initiating a cell signaling cascade that influences cell movement.

Our in vitro experiments demonstrated that biologically active HGF was released into the medium of nasal explants. In the motogenic assay, this medium induced a scatter response in MDCK cells, which was blocked by HGF-neutralizing antibody. HGF was released into the nasal explant medium in the initial period of GnRH-1 neuronal migration and olfactory axon elongation. Anti-HGF treatment significantly stunted GnRH-1 migratory behavior and olfactory axon outgrowth (elongation or orientation), supporting endogenous HGF acting as a motogen on GnRH-1 neurons and a growth promoter for olfactory axons. 
When GnRH-1 cells were subject to exogenous uniform HGF concentrations, the cells did migrate farther and kept their spatial orientation. No effect was observed in terms of olfactory axon growth, in contrast with olfactory axon changes detected in the blocking-function experiments. This apparent discrepancy may result because olfactory axon extension cannot be stimulated above an intrinsic limit or a limit imposed by general fibroblast outgrowth. Therefore, exogenous HGF might be insufficient to promote additional elongation of olfactory axons.

After HGF exposure, parallel changes were not detected in the GnRH-1 and olfactory system. Thus, the changes observed in GnRH-1 cell migration do not appear to be an effect dependent on alterations in olfactory axon outgrowth and suggest that the HGF effect on the motility of GnRH-1 neurons is in fact cell autonomous. It is important to note that, although anti-HGF treatment induced a striking accumulation of cells and olfactory fibers closer to the nasal explant tissue mass, it did not prevent GnRH-1 cells and peripherin-positive fibers from moving/extending into the periphery of the explant. Likely, residual HGF and perhaps other factors present in the nasal explants contribute to the initiation of cell movement and olfactory axon outgrowth.

We showed previously that HGF acts as a chemoattractant for immortalized GnRH-1 cells (Giacobini et al., 2002). Organotypic slices have been shown previously to contain the conditions necessary to allow GnRH-1 migration from the developing olfactory system to the basal forebrain while keeping intact their migratory route (Tobet et al., 1996). Thus, retained in these slices are the guidance cues for GnRH-1/olfactory system development that are clearly lacking in immortalized cells. In addition, some phenotypic/behavioral traits of the cell lines could be a consequence of the immortalization procedure which may alter the expression pattern and the activity of such cells (Martinez de la Escalera and Clapp, 2001). Thus, to evaluate whether HGF acts as a guidance cue during the migration of primary GnRH-1 neurons, we used tissue slices prepared from mouse embryos (Tobet et al., 1996; Bless et al., 2000). Tissue slices that maintain connection between forebrain and nasal compartment were generated from E12.5 whole heads. Embryonic slices were cocultured with aggregates of EGFP-HGF-transfected cells. In these experiments, after $1 \mathrm{~d}$ in vitro, GnRH-1 neurons accumulated in the nasal region when slices were cocultured with HGF-releasing transfected cell aggregates placed in an opposite direction with respect to the normal GnRH-1 migratory pathway.

The disruption of GnRH-1 cell motility observed in these experiments may result from their exposure to two attractive HGF gradients (one endogenous and one exogenous) acting from two opposite sites or from threshold concentrations of exogenous HGF, which fail to generate a motogenic response. In these in vitro coculture experiments, no alterations were observed in peripherin-positive olfactory/vomeronasal nerve axons among treatment groups, suggesting that the observed HGF-induced GnRH-1 neuronal migration defect is cell autonomous. However, it should also be noted that, at E12.5, olfactory fibers could no longer be sensitive to HGF stimulation, as they have started to contact their tissue target (i.e., the presumptive olfactory bulbs). In fact, it is known that at E1 1 in the mouse, axons begin to extend from the OE, forming small fascicles which pierce the basal lamina (Marin-Padilla and Amieva, 1989).

HGF-induced activity requires proteolytic processing, which is, at least in part, operated through enzymatic cleavage by PAs (Naldini et al., 1992; Mars et al., 1993). Mice carrying combined deficiencies for tPA and uPA genes are subfertile (Carmeliet et al., 1994), consistent with the hypothesis that the lack of tPA and uPA genes prevents active HGF from promoting GnRH-1 neuronal migration into the forebrain. To examine this possibility, the number of GnRH-1 neurons in adult brains of $\mathrm{tPA}^{-1-}: \mathrm{uPA}^{-1-}$ mice was compared with those of WT animals. The lack of tPA and uPA clearly affected the size of the GnRH-1 neuronal population, decreasing the number of GnRH-1 cells detected in brain. Whether this effect is directly related to loss of active HGF on GnRH-1 neurons or to additional mechanisms affecting GnRH-1 differentiation or cell survival will require additional investigations.

Very little is known about early interactions between migrating GnRH-1 neurons and the nasal mesenchyme, which lead to proper initial movement from the presumptive VNO toward the rostral forebrain. Our results are consistent with a role for HGF as a motogen as well as a chemotactic signal for developing $\mathrm{GnRH}-1$ neurons, acting to positively modulate cell-cell and cell-ECM interactions during the early aspects of their migratory process.

\section{References}

Achim CL, Katyal S, Wiley CA, Shiratori M, Wang G, Oshika E, Petersen BE, Li JM, Michalopoulos GK (1997) Expression of HGF and cMet in the developing and adult brain. Brain Res Dev Brain Res 102:299-303.

Baron U, Freundlieb S, Gossen M, Bujard H (1995) Co-regulation of two gene activities by tetracycline via a bidirectional promoter. Nucleic Acids Res 23:3605-3606.

Bladt F, Riethmacher D, Isenmann S, Aguzzi A, Birchmeier C (1995) Essential role for the c-met receptor in the migration of myogenic precursor cells into the limb bud. Nature 376:768-771.

Bless EP, Westaway WA, Schwarting GA, Tobet SA (2000) Effects of gamma-aminobutyric acid(A) receptor manipulation on migrating gonadotropin-releasing hormone neurons through the entire migratory route in vivo and in vitro. Endocrinology 141:1254-1262.

Calof AL, Chikaraishi DM (1989) Analysis of neurogenesis in a mammalian neuroepithelium: proliferation and differentiation of an olfactory neuron precursor in vitro. Neuron 3:115-127.

Cariboni A, Rakic S, Liapi A, Maggi R, Goffinet A, Parnavelas JG (2005) Reelin provides an inhibitory signal in the migration of gonadotropinreleasing hormone neurons. Development 132:4709-4718.

Carmeliet P, Schoonjans L, Kieckens L, Ream B, Degen J, Bronson R, De Vos R, van den Oord JJ, Collen D, Mulligan RC (1994) Physiological consequences of loss of plasminogen activator gene function in mice. Nature 368:419-424.

Caton A, Hacker A, Naeem A, Livet J, Maina F, Bladt F, Klein R, Birchmeier C, GuthrieS (2000) The branchial arches and HGF are growth-promoting and chemoattractant for cranial motor axons. Development 127:1751-1766.

Chan AM, King HW, Deakin EA, Tempest PR, Hilkens J, Kroezen V, Edwards DR, Wills AJ, Brookes P, Cooper CS (1988) Characterization of the mouse met proto-oncogene. Oncogene 2:593-599.

Crepaldi T, Gautreau A, Comoglio PM, Louvard D, Arpin M (1997) Ezrin is an effector of hepatocyte growth factor-mediated migration and morphogenesis in epithelial cells. J Cell Biol, 138:423-434.

Cronin AS, Horan TL, Spergel DJ, Brooks AN, Hastings MH, Ebling FJ (2004) Neurotrophic effects of BDNF on embryonic gonadotropinreleasing hormone $(\mathrm{GnRH})$ neurons. Eur J Neurosci 20:338-344.

Dulac C, Axel R (1995) A novel family of genes encoding putative pheromone receptors in mammals. Cell 83:195-206.

Ebens A, Brose K, Leonardo ED, Hanson Jr MG, Bladt F, Birchmeier C, Barres BA, Tessier-Lavigne M (1996) Hepatocyte growth factor/scatter factor is an axonal chemoattractant and a neurotrophic factor for spinal motor neurons. Neuron 17:1157-1172.

Friedman GC, Seeds NW (1994) Tissue plasminogen activator expression in the embryonic nervous system. Brain Res Dev Brain Res 81:41-49.

Fueshko S, Wray S (1994) LHRH cells migrate on peripherin fibers in embryonic olfactory explant cultures: an in vitro model for neurophilic neuronal migration. Dev Biol 166:331-348.

Fueshko SM, Key S, Wray S (1998) GABA inhibits migration of luteinizing hormone-releasing hormone neurons in embryonic olfactory explants. J Neurosci 18:2560-2569.

Gamble JA, Karunadasa DK, Pape JR, Skynner MJ, Todman MG, Bicknell RJ, Allen JP, Herbison AE (2005) Disruption of ephrin signaling associates 
with disordered axophilic migration of the gonadotropin-releasing hormone neurons. J Neurosci 25:3142-3150.

Giacobini P, Giampietro C, Fioretto M, Maggi R, Cariboni A, Perroteau I, Fasolo A (2002) Hepatocyte growth factor/scatter factor facilitates migration of GN-11 immortalized LHRH neurons. Endocrinology 143:3306-3315.

Giacobini P, Kopin AS, Beart PM, Mercer LD, Fasolo A, Wray S (2004) Cholecystokinin modulates migration of gonadotropin-releasing hormone-1 neurons. J Neurosci 24:4737-4748.

Gill JC, Tsai PS (2006) Expression of a dominant negative FGF receptor in developing GNRH1 neurons disrupts axon outgrowth and targeting to the median eminence. Biol Reprod 74:463-472.

Gill JC, Moenter SM, Tsai PS (2004) Developmental regulation of gonadotropin-releasing hormone neurons by fibroblast growth factor signaling. Endocrinology 145:3830-3839.

Gonzalez-Martinez D, Hu Y, Bouloux PM (2004) Ontogeny of GnRH and olfactory neuronal systems in man: novel insights from the investigation of inherited forms of Kallmann's syndrome. Front Neuroendocrinol 25:108-130.

Gossen M, Bujard H (1992) Tight control of gene expression in mammalian cells by tetracycline-responsive promoters. Proc Natl Acad Sci USA 89:5547-5551.

Gutierrez H, Dolcet X, Tolcos M, Davies A (2004) HGF regulates the development of cortical pyramidal dendrites. Development 131:3717-3726.

Ieraci A, Forni PE, Ponzetto C (2002) Viable hypomorphic signaling mutant of the Met receptor reveals a role for hepatocyte growth factor in postnatal cerebellar development. Proc Natl Acad Sci USA 99:15200-15205.

Ji JF, He BP, Dheen ST, Tay SS (2004) Interactions of chemokines and chemokine receptors mediate the migration of mesenchymal stem cells to the impaired site in the brain after hypoglossal nerve injury. Stem Cells 22:415-427.

Jung W, Castren E, Odenthal M, Vande Woude GF, Ishii T, Dienes HP, Lindholm D, Schirmacher P (1994) Expression and functional interaction of hepatocyte growth factor-scatter factor and its receptor c-met in mammalian brain. J Cell Biol 126:485-494.

Korhonen L, Sjoholm U, Takei N, Kern MA, Schirmacher P, Castren E, Lindholm D (2000) Expression of c-Met in developing rat hippocampus: evidence for HGF as a neurotrophic factor for calbindin D-expressing neurons. Eur J Neurosci 12:3453-3461.

Kramer PR, Wray S (2000) Novel gene expressed in nasal region influences outgrowth of olfactory axons and migration of luteinizing hormonereleasing hormone (LHRH) neurons. Genes Dev 14:1824-1834.

Kramer PR, Krishnamurthy R, Mitchell PJ, Wray S (2000) Transcription factor activator protein-2 is required for continued luteinizing hormonereleasing hormone expression in the forebrain of developing mice. Endocrinology 141:1823-1838.

LaMantia AS, Bhasin N, Rhodes K, Heemskerk J (2000) Mesenchymal/epithelial induction mediates olfactory pathway formation. Neuron 28:411-425.

Leonardsson G, Peng XR, Liu K, Nordstrom L, Carmeliet P, Mulligan R, Collen D, Ny T (1995) Ovulation efficiency is reduced in mice that lack plasminogen activator gene function: functional redundancy among physiological plasminogen activators. Proc Natl Acad Sci USA 92:12446-12450.

Maina F, Hilton MC, Ponzetto C, Davies AM, Klein R (1997) Met receptor signaling is required for sensory nerve development and HGF promotes axonal growth and survival of sensory neurons. Genes Dev 11:3341-3350.

Marin-Padilla M, Amieva MR (1989) Early neurogenesis of the mouse olfactory nerve: Golgi and electron microscopic studies. J Comp Neurol 288:339-352.

Mars WM, Zarnegar R, Michalopoulos GK (1993) Activation of hepatocyte growth factor by the plasminogen activators uPA and tPA. Am J Pathol 143:949-958.

Martinez de la Escalera G, Clapp C (2001) Regulation of gonadotropinreleasing hormone secretion: insights from GT1 immortal GnRH neurons. Arch Med Res 32:486-498.

Miragall F, Kadmon G, Schachner M (1989) Expression of L1 and N-CAM cell adhesion molecules during development of the mouse olfactory system. Dev Biol 135:272-286.

Montesano R, Matsumoto K, Nakamura T, Orci L (1991) Identification of a fibroblast-derived epithelial morphogen as hepatocyte growth factor. Cell 67:901-908.

Nakamura T, Nishizawa T, Hagiya M, Seki T, Shimonishi M, Sugimura A, Tashiro K, Shimizu S (1989) Molecular cloning and expression of human hepatocyte growth factor. Nature 342:440-443.

Naldini L, Tamagnone L, Vigna E, Sachs M, Hartmann G, Birchmeier W, Daikuhara Y, Tsubouchi H, Blasi F, Comoglio PM (1992) Extracellular proteolytic cleavage by urokinase is required for activation of hepatocyte growth factor/scatter factor. EMBO J 11:4825-4833.

Powell EM, Mars WM, Levitt P (2001) Hepatocyte growth factor/scatter factor is a motogen for interneurons migrating from the ventral to dorsal telencephalon. Neuron 30:79-89.

Powell EM, Campbell DB, Stanwood GD, Davis C, Noebels JL, Levitt P (2003) Genetic disruption of cortical interneuron development causes region- and GABA cell type-specific deficits, epilepsy, and behavioral dysfunction. J Neurosci 23:622-631.

Pronina T, Ugrumov M, Adamskaya E, Kuznetsova T, Shishkina I, Babichev V, Calas A, Tramu G, Mailly P, Makarenko I (2003) Influence of serotonin on the development and migration of gonadotropin-releasing hormone neurones in rat foetuses. J Neuroendocrinol 15:549-558.

Schmidt C, Bladt F, Goedecke S, Brinkmann V, Zschiesche W, Sharpe M, Gherardi E, Birchmeier C (1995) Scatter factor/hepatocyte growth factor is essential for liver development. Nature 373:699-702.

Schwanzel-Fukuda M, Bick D, Pfaff DW (1989) Luteinizing hormonereleasing hormone (LHRH)-expressing cells do not migrate normally in an inherited hypogonadal (Kallmann) syndrome. Brain Res Mol Brain Res 6:311-326.

Schwarting GA, Kostek C, Bless EP, Ahmad N, Tobet SA (2001) Deleted in colorectal cancer (DCC) regulates the migration of luteinizing hormonereleasing hormone neurons to the basal forebrain. J Neurosci 21:911-919.

Schwarting GA, Raitcheva D, Bless EP, Ackerman SL, Tobet S (2004) Netrin 1 -mediated chemoattraction regulates the migratory pathway of LHRH neurons. Eur J Neurosci 19:11-20.

Schwarting GA, Henion TR, Nugent JD, Caplan B, Tobet S (2006) Stromal cell-derived factor-1 (chemokine C-X-C motif ligand 12) and chemokine $\mathrm{C}-\mathrm{X}-\mathrm{C}$ motif receptor 4 are required for migration of gonadotropinreleasing hormone neurons to the forebrain. J Neurosci 26:6834-6840.

Seeds NW, Siconolfi LB, Haffke SP (1997) Neuronal extracellular proteases facilitate cell migration, axonal growth, and pathfinding. Cell Tissue Res 290:367-370.

Segarra J, Balenci L, Drenth T, Maina F, Lamballe F (2005) Combined signaling through ERK, PI3K/AKT, and RAC1/p38 is required for mettriggered cortical neuron migration. J Biol Chem 281:4771-4778.

Simonian SX, Herbison AE (2001) Differing, spatially restricted roles of ionotropic glutamate receptors in regulating the migration of $\mathrm{GnRH}$ neurons during embryogenesis. J Neurosci 21:934-943.

Son B-R, Marquez-Curtis LA, Kucia M, Wysoczynski M, Turner AR, Ratajczak J, Ratajczak MZ, Janowska-Wieczorek A (2006) Migration of bone marrow and cord blood mesenchymal stem cells in vitro is regulated by stromal-derived factor-1-CXCR4 and hepatocyte growth factor-c-met axes and involves matrix metalloproteinases. Stem Cells 24:1254-1264.

Sonnenberg E, Meyer D, Weidner KM, Birchmeier C (1993) Scatter factor/ hepatocyte growth factor and its receptor, the c-met tyrosine kinase, can mediate a signal exchange between mesenchyme and epithelia during mouse development. J Cell Biol 123:223-235.

Stella MC, Comoglio PM (1999) HGF: a multifunctional growth factor controlling cell scattering. Int J Biochem Cell Biol 31:1357-1362.

Stoker M, Gherardi E, Perryman M, Gray J (1987) Scatter factor is a fibroblast-derived modulator of epithelial cell mobility. Nature 327:239-242.

Streit AC, Stern CD (1997) Competence for neural induction: HGF/SF, HGF1/MSP and the c-Met receptor. Ciba Found Symp 212:155-165; discussion $165-168$.

Tashiro K, Hagiya M, Nishizawa T, Seki T, Shimonishi M, Shimizu S, Nakamura T (1990) Deduced primary structure of rat hepatocyte growth factor and expression of the mRNA in rat tissues. Proc Natl Acad Sci USA 87:3200-3204.

Thewke DP, Seeds NW (1996) Expression of hepatocyte growth factor/scatter factor, its receptor, c-met, and tissue-type plasminogen activator during development of the murine olfactory system. J Neurosci 16:6933-6944.

Thewke DP, Seeds NW (1999) The expression of mRNAs for hepatocyte 
growth factor/scatter factor, its receptor c-met, and one of its activators tissue-type plasminogen activator show a systematic relationship in the developing and adult cerebral cortex and hippocampus. Brain Res 821:356-367.

Toba Y, Temple JL, Wray S (2004) The stromal cell-derived factor-1/ CXCR4 ligand-receptor modulates development of the GnRH-1 neuronal system in mouse. Soc Neurosci Abstr 30:491.11.

Tobet SA, Schwarting GA (2006) Minireview: recent progress in gonadotropin-releasing hormone neuronal migration. Endocrinology 147:1159-1165.

Tobet SA, Hanna IK, Schwarting GA (1996) Migration of neurons containing gonadotropin releasing hormone $(\mathrm{GnRH})$ in slices from embryonic nasal compartment and forebrain. Brain Res Dev Brain Res 97:287-292.

Uehara Y, Minowa O, Mori C, Shiota K, Kuno J, Noda T, Kitamura N (1995) Placental defect and embryonic lethality in mice lacking hepatocyte growth factor/scatter factor. Nature 373:702-705.

Urbanek K, Rota M, Cascapera S, Bearzi C, Nascimbene A, De Angelis A, Hosoda T, Chimenti S, Baker M, Limana F, Nurzynska D, Torella D, Rotatori F, Rastaldo R, Musso E, Quaini F, Leri A, Kajstura J, Anversa P (2005) Cardiac stem cells possess growth factor-receptor systems that after activation regenerate the infarcted myocardium, improving ventricular function and long-term survival. Circ Res 97:663-673.

Vasyutina E, Stebler J, Brand-Saberi B, Schulz S, Raz E, Birchmeier C (2005) CXCR4 and Gab1 cooperate to control the development of migrating muscle progenitor cells. Genes Dev 19:2187-2198.

Wang SS, Tsai RY, Reed RR (1997) The characterization of the Olf-1/EBFlike HLH transcription factor family: implications in olfactory gene regulation and neuronal development. J Neurosci 17:4149-4158.
Wierman ME, Pawlowski JE, Allen MP, Xu M, Linseman DA, Nielsen-Preiss S (2004) Molecular mechanisms of gonadotropin-releasing hormone neuronal migration. Trends Endocrinol Metab 15:96-102.

Wray S (2002) Development of gonadotropin-releasing hormone-1 neurons. Front Neuroendocrinol 23:292-316.

Wray S, Gahwiler BH, Gainer H (1988) Slice cultures of LHRH neurons in the presence and absence of brainstem and pituitary. Peptides 9:1151-1175.

Wray S, Grant P, Gainer H (1989) Evidence that cells expressing luteinizing hormone-releasing hormone mRNA in the mouse are derived from progenitor cells in the olfactory placode. Proc Natl Acad Sci USA 86:8132-8136.

Wray S, Key S, Qualls R, Fueshko SM (1994) A subset of peripherin positive olfactory axons delineates the luteinizing hormone releasing hormone neuronal migratory pathway in developing mouse. Dev Biol $166: 349-354$.

Yamamoto Y, Livet J, Pollock RA, Garces A, Arce V, deLapeyriere O, Henderson CE (1997) Hepatocyte growth factor (HGF/SF) is a muscle-derived survival factor for a subpopulation of embryonic motoneurons. Development 124:2903-2913.

Yoshida K, Tobet SA, Crandall JE, Jimenez TP, Schwarting GA (1995) The migration of luteinizing hormone-releasing hormone neurons in the developing rat is associated with a transient, caudal projection of the vomeronasal nerve. J Neurosci 15:7769-7777.

Yoshida K, Rutishauser U, Crandall JE, Schwarting GA (1999) Polysialic acid facilitates migration of luteinizing hormone-releasing hormone neurons on vomeronasal axons. J Neurosci 19:794-801. 